Hydrol. Earth Syst. Sci., 15, 2995-3015, 2011

www.hydrol-earth-syst-sci.net/15/2995/2011/

doi:10.5194/hess-15-2995-2011

(C) Author(s) 2011. CC Attribution 3.0 License.

\title{
Creating a catchment scale perspective for river restoration
}

\author{
L. Benda ${ }^{1}$, D. Miller ${ }^{1}$, and J. Barquín ${ }^{2}$ \\ ${ }^{1}$ Earth Systems Institute, Mt. Shasta, California, Seattle, Washington, USA \\ ${ }^{2}$ IH-Cantabria, Universidad de Cantabria, Avda. Los Castros s/n, 39005, Santander (Cantabria), Spain \\ Received: 8 February 2011 - Published in Hydrol. Earth Syst. Sci. Discuss.: 25 March 2011 \\ Revised: 7 July 2011 - Accepted: 15 August 2011 - Published: 27 September 2011
}

\begin{abstract}
One of the major challenges in river restoration is to identify the natural fluvial landscape in catchments with a long history of river control. Intensive land use on valley floors often predates the earliest remote sensing: levees, dikes, dams, and other structures alter valley-floor morphology, river channels and flow regimes. Consequently, morphological patterns indicative of the fluvial landscape including multiple channels, extensive floodplains, wetlands, and fluvial-riparian and tributary-confluence dynamics can be obscured, and information to develop appropriate and cost effective river restoration strategies can be unavailable. This is the case in the Pas River catchment in northern Spain $\left(650 \mathrm{~km}^{2}\right)$, in which land use and development have obscured the natural fluvial landscape in many parts of the basin. To address this issue we used computer tools to examine the spatial patterns of fluvial landscapes that are associated with five domains of hydro-geomorphic processes and landforms. Using a 5-m digital elevation model, valley-floor surfaces were mapped according to elevation above the channel and proximity to key geomorphic processes. The predicted fluvial landscape is patchily distributed according to hillslope and valley topography, river network structure, and channel elevation profiles. The vast majority of the fluvial landscape in the main segments of the Pas River catchment is presently masked by human infrastructure, with only $15 \%$ not impacted by river control structures and development. The reconstructed fluvial landscape provides a catchment scale context to support restoration planning, in which areas of potential ecological productivity and diversity could be targeted for in-channel, floodplain and riparian restoration projects.
\end{abstract}

Correspondence to: L. Benda

(leebenda@earthsystems.net)

\section{Introduction}

There is a growing consensus that a catchment scale perspective that considers the complete fluvial landscape is critical for successful river restoration (Logan and Furze, 2002; Bannister et al., 2005; Kondolf et al., 2007; Nilsson et al., 2007). The fluvial landscape includes all landforms and biologic communities that affect and are affected by the flow of water, sediment and organic materials within the hierarchically branching network of river corridors. The fluvial landscape is comprised of active and former river and side channels, offchannel water bodies, confluence environments, wetlands, floodplains, terraces, and riparian vegetation (Fausch et al., 2002; Benda et al., 2004a), and subsurface patterns of hyporheic flow and associated organisms (Poole et al., 2006).

The processes and landforms that comprise the fluvial landscape vary with location in a catchment governed by hillslope and valley topography, river network structure, channel elevation profiles, basin scale, and the stochastic nature of climate (Frissel and Nawa, 1992; Reeves et al., 1995; Naiman et al., 1992; Poff et al., 1997; Benda et al., 1998; Ward et al., 2002). The fluvial landscape is thus a dynamic entity, formed and altered over time by the storms, erosion and floods that bring water, sediment and organic material downslope and downstream from all points in a catchment.

Regulating discharge with dams and weirs, hardening channel banks with revetments, constructing dikes and levees, dredging channels, and draining wetlands have furthered human occupation and development of productive, flood prone lands. However, these activities individually, and in concert, have acted to eliminate the fluvial landscape or to obscure evidence of it over the last couple of centuries (Sedell and Luchessa, 1981; Logan and Furze, 2002). River control activities have reduced in-channel and off-channel

Published by Copernicus Publications on behalf of the European Geosciences Union. 
habitats important to many aquatic species, reduced the renewal of sediment and organic material reservoirs important to riparian plants and animals, altered the riparian groundwater and hyporheic flow systems, and have led to species declines or extirpations.

To counteract impacts to riparian and aquatic ecosystems resulting from centuries of human development, the discipline of river restoration is aimed at reestablishing natural patterns and processes within the fluvial landscape and thus restoring aquatic and riparian habitats. River restoration planning, design and implementation (levee removal, channel engineering, placement of in stream structures, planting riparian vegetation, etc.) necessarily and typically occur at the scale of individual channel reaches $(100-1000 \mathrm{~m})$ (Rosgen, 1996; Wohl et al., 2005). However, local restoration projects can be more effective if they are designed using a catchment (fluvial landscape) context to strategically place them for the greatest ecological benefit (Thoms and Parsons, 2002; Gilvear and Casas, 2008). A catchment scale perspective provides a larger frame of reference for smaller scale projects, such as how valley form, river network structure and natural disturbances (floods, fires, landsliding) affect restoration projects positively or negatively. Restoration activities within the framework of a catchment perspective can target meso-scale habitats such as large floodplains and islands (Jähnig et al., 2010) or confluence environments (Benda et al., 2004a) and can include measures such as levee pullback, re-meandering, food embankment removal, buffer strip creation, reconnection of side channels, and wetland development (Gilvear and Casas, 2008).

Design of a river-restoration strategy requires two important steps: (1) recognizing the spatial and temporal characteristics of the fluvial landscape, unique to some degree for every river system, that govern geomorphic and ecosystem interactions (referred to as a "guiding ecological image" (Palmer et al., 2005) or a "geomorphic template" (Brierly et al., 2008), and (2) recognizing human alterations to the fluvial system and the consequences for geomorphic and ecological processes. Although information from satellite imagery, aerial photography, field surveys, and data on land use and local biology can inform descriptions of fluvial landscapes, information on a reference condition may not be available in catchments with extensive and long-term human development.

In this paper we outline a new approach for creating a catchment scale perspective for river restoration planning. We illustrate how hydro-geomorphic principles can be evaluated with computer analysis tools to characterize fluvial landscapes in catchments where they have been mostly obscured by extensive land use. We apply our approach to the Pas River basin $\left(650 \mathrm{~km}^{2}\right)$, located in the Cantabria Region of Northern Spain, that has a long history of land development extending back to Neolithic times ( $4000 \mathrm{ybp}$ ) but accelerating beginning in the 17th century; river control structures include 50 bridges, 24 weirs and minor dams $(<10 \mathrm{~m})$, and

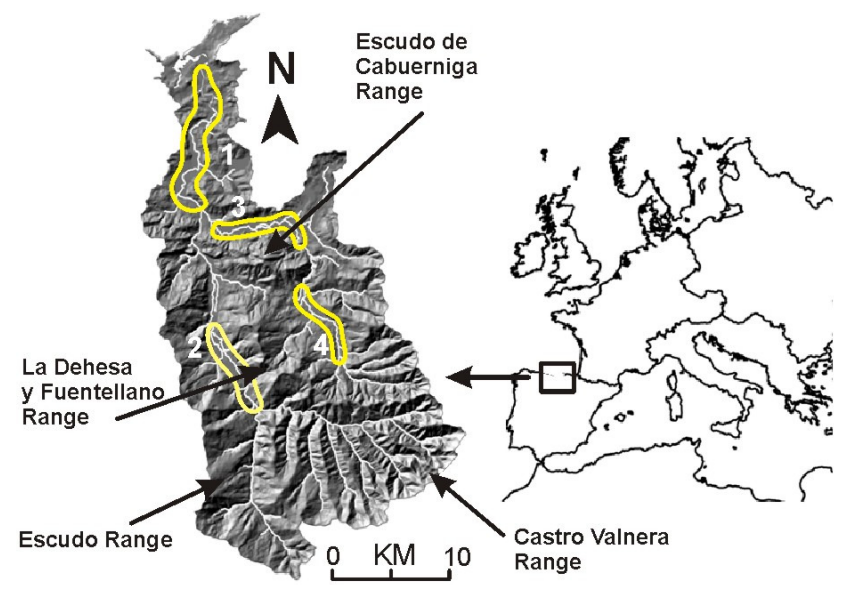

Fig. 1. The study area is the Pas River basin $\left(650 \mathrm{~km}^{2}\right)$ located in the northern part of Spain in the Cantabria region. The surface areas of the fluvial landscapes in the valleys outlined in \#1-\#4 were measured using 2010 Google Earth imagery.

more than 120 engineered works (levees and dikes) for flood protection and urban development (GESHA, 2005a).

The steps in our analysis include: (1) defining the natural fluvial landscape in the Pas River catchment; (2) evaluating how the fluvial landscape is created and influenced by topography, valley morphology, river network structure, basin scale and other landforms and processes; (3) comparing the current, regulated fluvial landscape with the natural fluvial landscape that we infer from our analysis; and (4) describing how our analysis can provide a catchment scale context for restoration planning, including identifying a provisional set of candidate areas for restoration.

\section{Study area}

The Pas River catchment $\left(650 \mathrm{~km}^{2}\right)$ is located in the province of Cantabria, northern Spain, and drains northwards to the Atlantic Ocean (Fig. 1). The Pas river is flanked by the Escudo Mountain Range (1328 m) on the west, the Castro Valnera Massif $(1718 \mathrm{~m})$ on the south and the Sopeña Mountain Range and Las Enguinzas Massif on the east $(1240 \mathrm{~m}$ and $964 \mathrm{~m}$, respectively). The La Dehesa and Fuentellano Mountain Range (1238 m) divides the main Pas and Pisueña tributaries (West and East Forks), while the Escudo de Cabuérniga Mountain Range constrains both West and East Forks at about $20 \mathrm{~km}$ from the river mouth (Fig. 1). Sandstones, conglomerates and shales dominate within the Escudo the Escudo de Cabuérniga Mountain Range. Lower cretaceous limestone mixed with sandstone is also present in the Castro Valnera Massif, and dominates in the Las Enguinzas Massif (IGME, 1989).

The Pas river catchment has a humid temperate climate with an average annual temperature and precipitation ranging from $14{ }^{\circ} \mathrm{C}$ to $8^{\circ} \mathrm{C}$ and from $1200 \mathrm{~mm}$ to $2500 \mathrm{~mm}$ from the 
coast to mountains. Snow is common from late autumn to early spring above $1000 \mathrm{~m}$. Rainfall is regularly distributed throughout the year with maximums in winter and spring. Mean annual flow in the Pas river basin is $15.4 \mathrm{~m}^{3} \mathrm{~s}^{-1}$, with the largest spates concentrated between November and April (mean annual maximum flow is $215 \mathrm{~m}^{3} \mathrm{~s}^{-1}$ ) and dry periods from August to November (mean annual minimum flow is $1.6 \mathrm{~m}^{3} \mathrm{~s}^{-1}$ ) (GESHA, 2005b).

The coastal forest, below $400 \mathrm{~m}$, is mainly composed of ash (Fraxinus excelsior), lime (Tilia sp.), hazelnut (Corylus avellana), maple (Acer sp.), oak (Quercus sp.), poplar (Populus sp.) and holm oak (Quercus ilex). Currently, eucalyptus plantations (Eucalyptus globulus) and pastures dominate the coastal area. Vegetation between 400 to $1100 \mathrm{~m}$ includes oak (Quercus robur and Q. petraea) dominating on the southern slopes and beech (Fagus sylvatica) and holly (Ilex aquifolium) on the northern slopes. This vegetation belt has been highly modified by pasture land. Higher in the catchment (1100 to $1800 \mathrm{~m})$ vegetation is dominated by birch (Betula sp.), heath (Genista sp., Erica sp. and Ulex sp.) and mountain grassland.

The riparian vegetation is dominated by black alder (Alnus glutinosa) from sea level up to $700 \mathrm{~m}$ (Lara et al., 2004). Willow (Salix atrocinerea) replace alder in areas where human activities have impacted natural vegetation, or where soils are not deep enough, or where there are large flow fluctuations. Higher in altitude, alder is replaced by ash or by hazelnut (C. avellana). In modified river banks for flood protection or where agriculture and cattle activities are intensive, riparian vegetation is usually dominated by bramble (Rubus sp.), rose (Rosa sp.), hawthorn (Crataegus monogyna), blackthorn (Prunus spinosa) or even pasture.

The first evidences of human settlements in the Pas river catchment are from the upper Paleolithic (40000$10000 \mathrm{ybp}$ ), indicated by cave paintings from Monte Castillo. Beginning in the 16th century, population densities increased along with numerous land use modifications (Delgado, 2003). Human population density rapidly increased during the 17 th and 18 th centuries in the main villages of the catchment with a concurrent increase in pasture land for cattle (Delgado, 2003). During this period forests were cleared for pasture but also to supply fire wood for the smelting industry (Alcala-Zamora, 2004). More recently, Eucalyptus and pine forestry and urban developments have extensively modified catchment vegetation, while flood protection and the need for water supply have modified the Pas River channel in many reaches, involving more than 55 bridges, 24 weirs and low-dams $(<10 \mathrm{~m}), 124$ engineered works (e.g., levees) and 20 water intakes within the catchment (GESHA, 2005a). Most water intakes along the catchment are for local use, except the major extraction that pipes water to the city of Santander, which is located just before the West Fork joins the East Fork.

Human population in the catchment reached 50986 inhabitants in 2010, although half of the population is concentrated near the river mouth. Population density fluctuates from $165 \mathrm{~km}^{-2}$ in the coast to $10 \mathrm{~km}^{-2}$ in the upper parts of the catchment.

The Pas River maintains a small population of Atlantic salmon (Salmo salar) in the southern most extent of the species range, although the fish has a threatened status (Costas et al., 2009). Other species include brown trout (Salmo trutta), minnow (Phoxinus bigerri,) with allis shad (Alosa Alosa), Ebro barbel (Luciobarbus graellsii), parachondostroma (Parachondrostoma miegii) found in the lower parts of the catchment (Doadrio, 2001). Other estuarine fish species that enter the fluvial freshwater habitat in the Pas River are European flounder (Platichthys flesus) and thicklip grey mullet (Chelon labrosus). A more in depth description of Pas river biological communities is described elsewhere (e.g., Álvarez-Cabria 2011; Barquín et al., 2011).

Because of the abundance of river control structures that impact riparian and aquatic habitats, the Pas River system could benefit from certain types of river restoration activities (Pas Water Authority). River restoration planning in the Pas River catchment is in its early stages and the analysis presented here could be used to help guide planning efforts.

\section{The fluvial landscape and general principles of hydro-geomorphic processes}

We define the fluvial landscape as that part of the valley floor that is periodically inundated by high flows and it can include channels (single and multiple), floodplains, wetlands, and low terraces. The fluvial landscape is characterized by channel-floodplain, fluvial-riparian and tributary-to-tributary (via confluence) interactions. General principles of hydrogeomorphic processes, universal in catchments, can inform the analysis of the fluvial landscape in controlled riverine environments where dikes, levees, and in-channel structures have altered or obscured it. We focus on network-scale processes and landforms, those most likely to be detected using computer tools in conjunction with remotely sensed information (e.g., digital elevation models, aerial photography, and satellite imagery). The general principles of hydro-geomorphic processes relevant to the Pas River cover five domains including: (1) valley geometry; (2) river network structure, including spatially variable supply of sediment and organic material; (3) hillslope and fan/terrace landforms; (4) river elevation profile and fluvial morphology; and (5) riverine-estuarine environments. A brief description of each of these is provided in turn.

\subsection{Valley geometry}

Geologic controls and major slope movements can create variations in valley width and shape. Constrained (narrow) valleys typically lack sediment storage while unconstrained (wide) valley segments act as reservoirs of alluvial sediment, 
often creating wide, more complex floodplains within the fluvial landscape (Grant and Swanson, 1995; McDowell, 2001). At the upstream transition from unconstrained to constrained valley segments, a bottleneck in the transfer of sediment can occur, often enhanced by logjams. Increased sediment storage at the transition promotes heightened connectivity between channels and adjacent valley floors. The transition from unconstrained to constrained segments also enhances hyporheic downwelling (Edwards, 1998). At the downstream transition from constrained to unconstrained valley segments, increased sediment deposition, flow divergence, and hyporheic upwelling can occur (Edwards, 1998). Thus, there is typically greater channel-valley connectivity and hence larger fluvial landscapes immediately above and below valley constrictions, with increased occurrence of floodplains, side channels, and riverine wetlands (Baxter, 2001). Alternating constrained and unconstrained river segments promote patchy heterogeneity in fluvial processes and riparian environments, a pattern often referred to as a "string of pearls" (Standford and Ward, 1988).

\subsection{River network structure, confluences and material flux}

Channel confluences juxtapose two separate flow and material flux regimes (sediment, coarse and fine organic material) with effects on channel and valley-floor morphology, water temperature, water chemistry and biota. Inputs of sediment from a tributary channel can result in locally heightened sediment storage near the confluence resulting in reduced elevation differences between channels and adjacent valley floors, leading to development of large floodplains, side channels, wetlands, and increased hyporheic flow and therefore an enlarged fluvial landscape (Grant and Swanson, 1995; Benda et al., 2004a). Other morphological changes observed at channel junctions include finer channel substrate, higher widthdepth ratios, pool formation, and increased meandering and braiding (Best, 1988; Church, 1983). Higher fluxes and storage of large organic material are also often located at tributary confluences (Bigelow et al., 2007). Attendant changes in aquatic biota include increased animal and plant productivity and diversity (Rice et al., 2001; Kiffney et al., 2006). Alluvial and debris-flow deposition at confluences is highly episodic, and the morphological (and ecological) imprints on valleys (e.g., floodplains, side channels, low terraces, higher biotic diversity) wax and wane over time due to the stochastic interactions of storms, floods, fires, and other perturbations (Benda et al., 2004a).

A large river system contains hundreds of channel confluences, involving a wide range of tributary and receiving channel sizes and inter-tributary spacing. Factors that are important when examining the role of tributaries, via confluences, on rivers include the basin shape and geometric structure of the river network that govern the size of the tributary relative to the size of the receiving channel, inter-confluence distances and the spatial frequency of confluences along channels, planform morphology of intersecting streams (tributaries running parallel or intersecting at right angles), erosion regimes of the tributary channels, and stochastic aspects of erosion and sediment supply (Benda et al., 2004b; Rice et al., 2008). Spatial patterns of confluences strongly influence the upstream and downstream transfer of abiotic and biotic materials and they are an important determinant to the migration of organisms (Eros et al., 2011).

The spatial pattern of erosion in a tributary catchment is driven by topography, lithology, soils, vegetation and climate. The resultant supply of sediment to a channel system is punctuated at confluences and it is organized by the spatial structure of a river network (Benda and Dunne, 1997a, b).

\subsection{Hillslope-Fan/Terrace landforms}

Where valley are narrow, hillslopes can impinge on channels and influence gradients, widths and stream orientation. Debris cones and fans created by rockfalls and landslides can form in numerous locations in a watershed displacing channels and creating alternating constrained and unconstrained valley segments (Ouimet et al., 2008), and thus contributing to variation in the fluvial landscape. Other fan landforms created by fluvial and debris flow processes at confluences can create spatially punctuated but repetitive channel morphology (e.g., boulder driven cascades and riffles). Terraces can form in conjunction with landslide, alluvial, and debris fan deposits and they can also influence valley width, further promoting formation of alternating constrained and unconstrained fluvial landscapes. Terrace formation may reflect large erosion and flood events in the present climate, different erosion and sedimentation regimes during past climates, or different river base levels due to past sea levels.

\subsection{Channel elevation profile - fluvial morphology}

River channels have a range of distinct morphologies (and habitat types) that are directly related to the valley elevation profile (e.g., gradients) (Schumm, 1977) as well as sediment supply (Montgomery and Buffington, 1997), confluence zones (Bigelow et al., 2007) and disturbance regimes (Benda and Dunne, 1997a, b). Distinct channel types include braided, meandering pool-riffle, step pool, and cascade.

Large streams and rivers with sediment availability in lowgradient valley settings typically meander and form extensive floodplains (Schumm, 1977). Floodplain environments often include multiple channels, wetlands and diverse riparian vegetation and thus they constitute an important component of the fluvial landscape. Where valleys are wide with actively meandering channels, hillslope-fan/terrace landforms and tributary confluences may have little effect. Meandering river and floodplain environments are often highly fertile and are usually associated with widespread human resource use, including development of agriculture, urban centers, 
and transportation systems. Typically river control occurs most aggressively in wide valley floors, including the building of dikes, levees, and in-channel flow weirs. From a river restoration perspective, a favored target and one that responds to many restoration techniques is the meandering pool-riffle morphology with its attendant floodplains.

\subsection{Mixed riverine-estuarine environments}

Near the mouth of mid to large rivers as they enter oceans, a mixed fluvial-estuarine environment typically forms and it may extend for several kilometers upstream (from the ocean) depending on river size, local valley morphology, and tide ranges. The meandering-braided river environment with its extensive floodplain can overlap with the brackish, lowgradient and fine-sediment estuarine area leading to highly diverse and productive fluvial landscapes. In mixed riverineestuarine environments, the elevation differences between channels and adjacent lands may be low due to frequent inundation of combined flood-tidal surges. In this environment, the effects of confluences, hillslope-fan/terrace forcing, and variable valley morphology will be minimal to non-existent. Mixed riverine-estuarine environments are often selected for human occupation and development. In addition to dikes and levees, engineering controls can include estuarine and channel dredging to reduce flooding and to allow for navigation.

In the analysis that follows, computer tools are used to examine the spatial patterns of fluvial landscapes that are associated with the five domains of hydro-geomorphic processes and landforms listed above.

\section{Methods}

We used available topographic data with the analysis toolkit "NetMap" (www.netmaptools.org; Benda et al., 2007, 2009) to examine relationships among valley geometry, rivernetwork structure, landforms, channel elevation profiles and the potential for channel-floodplain and confluence interactions. We used 2010 satellite imagery to map the current extent of the fluvial landscape in the Pas River catchment and to estimate the degree to which riverine processes are presently constrained by human land use.

The steps in the analysis (explained in greater detail below) included: (1) developing a synthetic, attributed (attributes include channel gradient, width, depth, elevation, and length) and routed stream layer using digital elevation data provided at $5-\mathrm{m}$ horizontal resolution and $0.1 \mathrm{~m}$ vertical resolution (the highest resolution available), (2) estimating the area of flood inundation adjacent to the channel at specified elevations above the channel in units of bankfull depths (bankfull depth refers to the depth of water in a channel of an elevation similar to the uppermost eroded banks and/or it refers to the depth of flow associated with a flood of an approximate two-year recurrence interval), (3) predicting the potential for tributaries to geomorphically and ecologically influence channels, (4) characterizing valley morphology in terms of degree of confinement, (5) predicting spatially variable sediment yields throughout the river network using a topographic index of erosion, (6) mapping across-valley profiles to determine valley-hillslope topography and identifying constraints on channel-valley connectivity, and (7) mapping the current extent of the active channel and floodplain surface area along the largest channels in the Pas River basin using satellite imagery (Google Earth).

A synthetic channel network was delineated using flow directions inferred from a 5-m digital elevation model (DEM); algorithms for flow direction and channel delineation are described by Clarke et al. (2008). GIS data on channel locations were used for drainage enforcement in low-relief areas. The channel network was divided into a linked set of channel segments (scale 10-100 m). Contributing area, channel length and channel gradient were calculated from the DEM for each segment; segment endpoints were located to minimize attribute variability. Bankfull channel width and depth were estimated using a regional regression of drainage area and mean annual precipitation to fieldmeasured widths and depths over a range of channel sizes encompassing 195 river sites (selected in areas with little to no engineered works) in the region of Cantabria: bankfull width $=1.683 *$ area $^{0.4365 *}$ precipitation $^{0.4408}$; bankfull depth $=0.63 *$ area $^{0.1731 *}$ precipitation ${ }^{0.1516}$.

To characterize valley-floor surfaces, DEM cells were classified according to elevation above the channel. Each cell within a specified radius $(1500 \mathrm{~m})$ of a channel is associated to the closest channel cell, with distance to the channel weighted by intervening relief. Valley-floor DEM cells are associated with channels that are closest in Euclidean distance and have the fewest and smallest intervening high points. The elevation difference between each valley floor cell and the associated channel location is normalized by bankfull depth and valley floors are characterized in terms of number of bankfull depths above the channel. This procedure is repeated for every channel segment.

Floodplains typically lie at, or somewhat above, bankfull stage (Dunne and Leopold, 1978). In practice, zones of frequent inundation are defined by an elevation above the channel equivalent to two bankfull depths (Rosgen, 1996; Castro, 1997). To illustrate a wide range of flow inundation-valley topography relations in the Pas River, we delineated surfaces above the DEM-inferred channel using elevation equivalents of one, two, and three bankfull depths. Estimated bankfull depths for the Pas River range from a little over $2 \mathrm{~m}$ at the mouth to a little over $1 \mathrm{~m}$ at the upstream extent of this analysis. We therefore delineate inundation depths between about 1 and $6 \mathrm{~m}$. Because elevations above the channel are referenced to a nearby location on the channel, the extent of the delineated area is dependent on the degree to which local elevation differences can be resolved with the DEM, rather than on the absolute accuracy of the elevation values. We do 
not know the accuracy to which the available 5-m DEM in the Pas River can resolve these elevation differences, without field verification our results must be viewed as a testable hypothesis.

The probability of observing confluence related changes in the morphology of mainstem channels (confluence effects) depends on the size of the tributary relative to the mainstem (Benda et al., 2004b). In the Pas River, a logistic regression equation was used to predict the probability of confluence effects as:

$P_{\mathrm{e}}=\exp (g(x)) / 1(1+\exp (g(s)))$

Where $\mathrm{P}_{\mathrm{e}}$ is the probability of a confluence effect and $g(x)$ is fitted to regional data in the western United States on confluence effects (in Benda et al., 2004b). Confluence effects are defined as wide floodplains, side channels, mid channel bars, meanders, terraces, log jams, deeper pools and changes in substrate. Based on Eq. (1) there is an $85 \%$ probability that a tributary with a drainage area one tenth that of the mainstem will create a confluence effect. The probability decreases to less than $10 \%$ for tributary basins that have a drainage area less than about $1 / 1000$ of the mainstem.

The spatial frequency of tributary intersections along the mainstem rivers was calculated over a moving window equivalent to four channel segments, ranging between approximately 0.5 to $2 \mathrm{~km}$ (average $0.9 \mathrm{~km}$ ).

In the Pas River average annual sediment yields were estimated using a topographic index of erosion. Erosion in the form of shallow landslides, gullies and surface erosion is often driven by slope steepness and slope convergence (Dietrich and Dunne, 1978; Sidle, 1987). To estimate a measure of erosion potential in the Pas River catchment, a dimensionless index that employs slope gradient and local topographic convergence was used (Miller and Burnett, 2007):

$\mathrm{GEP}=\left(A_{\mathrm{L}} * S\right) / b$

Where GEP is the "generic erosion potential", $b$ is a measure of local topographic convergence (the length of an elevation contour crossed by flow out of a pixel, values less than one pixel indicate convergent topography), $A_{\mathrm{L}}$ is a measure of local contributing area (within one pixel length) and $S$ is slope gradient (Miller and Burnett, 2007).

GEP was converted into average annual sediment yield by specifying a catchment average erosion or sediment yield rate, and then distributing that rate linearly according to the GEP index. High values of GEP yield average annual erosion rates in excess of the catchment mean value and low values of GEP yield erosion rates less than the catchment mean value. In the model, the cumulative sum (area weighted) of downstream routed GEP-based average sediment yields must equal the assigned catchment average at the mouth of the river. Estimated sediment yield rates in northern Spain that includes the Pas River basin range between 500 and $1500 \mathrm{t} \mathrm{km}^{-2} \mathrm{yr}^{-1}$ (Cerdá, 2001; Rodríguez-Blanco, 2011). Thus, we apply an sediment yield rate of $1000 \mathrm{t} \mathrm{km}^{-2} \mathrm{yr}^{-1}$.
The Pas River system was divided into three sections for our analysis: (1) the East Fork (Yera River), which is $35 \mathrm{~km}$ long, (2) the West Fork (Pisuena River), $60 \mathrm{~km}$ long, and (3) the Mainstem, extending downstream of the West Fork-East Fork confluence for about $20 \mathrm{~km}$ to where it enters the Liencres estuary.

We compared the extent of the topographically inferred fluvial landscape to the current extent of active channel surfaces mapped from 2010 satellite imagery available from Google Earth. The present day fluvial landscape (e.g., active channel and floodplain [unvegetated or lightly vegetated fluvial surfaces located adjacent to the channel]) was mapped in four areas of the Pas catchment (Fig. 1). Mapping was done only in the larger rivers where valley walls and riparian vegetation did not obscure the existing channel and gravel bars and where the fluvial landscape is bounded by human infrastructure including roads, agricultural fields and urban centers.

Our analysis is used to identify a provisional set of candidate channel-valley segments that would have the greatest potential for improving aquatic and riparian habitats through restoration. Candidate segments will have some combination of the following characteristics: wide floodplains (as depicted by valley floor elevations equivalent to one, two and three bankfull depths); significant tributary confluences; high spatial density of confluences; transitions in valley floor width (constrained to unconstrained and vice a versa); proximity to sources of sediment and organic material; and closely aligned, parallel running tributary-mainstem channels.

\section{Results}

\subsection{Characterizing fluvial landscapes in the Pas River}

Each of the three river sections presents a distinct downstream sequence of geomorphic attributes. Hence, even though the East and West Fork study sections contain a similar range of channel sizes and gradients, the fluvial landscapes differ between them. We describe results for each river section below. The predicted fluvial landscapes for all three bankfull depths are shown on the accompanying maps. For simplicity in our graphical depiction of the fluvial landscape, we used valley topography inferred from one and two bankfull depths elevations only.

\subsection{Mainstem}

Extending downstream of the confluence of the East and West Forks, the Mainstem study section has a drainage area of 560 to $640 \mathrm{~km}^{2}$. Predicted bankfull widths from the regional regression range from 21 to $34 \mathrm{~m}$ and depths from 1.7 to $2 \mathrm{~m}$ along its $20 \mathrm{~km}$ length. Predicted channel slopes (elevation change divided by intervening distance derived from NetMap's analysis of the 5-m DEM) in the Mainstem section 
range between 0.001 and 0.004 (Fig. 2). In the Mainstem segment, the widest zone of inundation at one bankfull depth (600-1200 m) and the least difference between the surface areas of the two fluvial landscapes occurs near the estuary between RK 0 to RK 4 (A in Figs. 3 and 4). This likely reflects the mixed riverine-estuarine environment where the elevation of channel-adjacent land surface is subtle (XS-1, 2, Fig. 5). Wide fluvial landscapes (200-800 m) are also predicted throughout the rest of the Mainstem segment ( $B$ in Figs. 3 and 4), but particularly between RK 10 and 18. Variation in the spatial extent of the fluvial landscape (one and two bankfull depths) indicates variation in valley floor elevations, likely reflecting the existence of terraces formed by historical river meandering. The presence of levees, or roads located on engineered elevated surfaces above the channel (that function as levees) can be detected on the 5-m DEM (e.g., XS-3, XS-4, Fig. 5). Channel constraining dikes can limit the extent of the predicted fluvial landscape using the 5-m DEM, particularly at one bankfull depth. The dikes become mostly irrelevant to the predicted extent of the fluvial landscape at an elevation equivalent to two and three bankfull depths.

Due to the very narrow basin width $(<5 \mathrm{~km})$ of the Mainstem segment, the confluence effects are predicted to be negligible (Fig. 3). Moreover, because of the lack of large tributaries the downstream gradient of average sediment yields is predicted to be flat, at about $1000 \mathrm{t} \mathrm{km}^{-2} \mathrm{yr}^{-1}$ (the catchment average). There is a high frequency of tributaries $(4-8 \mathrm{~km})$ in the middle portion of the Mainstem between approximately RK 8 and 14.

\subsection{West Fork}

The West Fork drains $360 \mathrm{~km}^{2}$ and has predicted bankfull widths up to $35 \mathrm{~m}$ and depths up to $2.1 \mathrm{~m}$. Estimated channel slopes range from 0.005 in the most downstream reaches to approximately 0.01 through the broad-valley segments between RK 20 and 30, and up to 0.03 in the upper watershed (Fig. 2). Very narrow fluvial corridors are predicted in two, several kilometer segments of the West Fork, one bounded by a high terrace (RK 16-22) and the other in a canyon at RK 22-26 (C, D in Figs. 3 and 4; XS-3 in Fig. 5). The high terrace is mapped as a Holocene fluvial landform (IGME, 1989) and the canyon segment is formed within the mechanically strong Dolomite rock of the Escudo de Cabuérniga Mountain Range.

Moving upstream, wide fluvial landscapes (200-1200 m) are predicted to occur within the broad valley of the West Fork between RK 25 and 40, although with considerable differences in surface area between one and two bankfull depths (E in Figs. 3 and 4; XS-4 and 5, Fig. 5). The differences between predicted fluvial corridors indicate variable valley floor elevations, likely reflecting the presence of terraces. The probability of confluence effects in the wide river valleys of the West Fork are less than 0.02 given the small size of the tributaries in relation to the drainage area of the mainstem channels (tributary area/mainstem area <0.08) (Fig. 3). Overall, the geomorphic effects of tributaries on the West Fork appear to be minimal. However, at least one high energy tributary intersects the West Fork directly (near the western valley wall) and it is associated with local widening of the fluvial landscape (Fig. 6). In addition, tributaries that flow parallel to the mainstem include their own fluvial landscapes that merge with the fluvial landscape of the West Fork (not shown).

Upstream in the West Fork there is a large meander (length $=1.5 \mathrm{~km}$ ) at RK 42 with an associated large fluvial landscape (400-700 m) at both one and two bankfull depths ( $\mathrm{F}$ in Figs. 3 and 4). The wide fluvial landscape there may be driven, in part, by the close proximity of the large tributary (and an increase in sediment supply) that enters from the south at RK 44.

Another large fluvial landscape occurs in association with the confluence at RK 44 ( $\mathrm{G}$ in Figs. 3 and 4). A $200 \mathrm{~m}$ to $300 \mathrm{~m}$ wide fluvial landscape is predicted to occur both upstream and downstream on the confluence (confluence probability $=0.25)$, in association also with the predicted increase in average sediment yield of $1250 \mathrm{t} \mathrm{km}^{-2} \mathrm{yr}^{-1}$ to $1400 \mathrm{t} \mathrm{km}^{-2} \mathrm{yr}^{-1}$.

Moving upstream in the West Fork along the narrower east-west trending valley, hillslopes, high terraces and alluvial fans bound both sides of the channel, thereby reducing the width of the fluvial landscape to less than $200 \mathrm{~m}(\mathrm{H}$ in Figs. 3 and 4). The potential importance of tributaries, via confluences, is more apparent along this segment. For example, there are numerous tributaries that are predicted to have the potential to create confluence effects along the $10 \mathrm{~km}$-long valley, including the building of fans and terraces between RK 50 and 60 (Fig. 3). In addition, tributaries along this portion of the West Fork are predicted to have average annual sediment yields in excess of $1500 \mathrm{t} \mathrm{km}^{-2} \mathrm{yr}^{-1}$ (Fig. 3), relatively high sediment yields entering channels of relatively low gradient (e.g., 1-3\%, Fig. 2). Unconstrained valley segments occur intermittently where elevation differences between channels and fan/terraces are less than about $4 \mathrm{~m}$ and constrained segments are typically bounded by fan/terraces of about 4 to $9 \mathrm{~m}$ in height (Fig. 7).

Upstream of RK 60, the West Fork valley narrows further and the fluvial landscape diminishes to less than $50 \mathrm{~m}$ wide, although the pattern of alternating wide and constrained reaches continues (I in Figs. 3 and 4).

The frequency of confluences along the West Fork study segment varies between 2 and 20 per kilometer and the higher frequencies may identify areas of greater geomorphological diversity and higher ecological potential. There are high confluence frequencies in the wide valley between RK 8 and 15, in the canyon segment (RK 22 to 28) and in the upper basin upstream of RK 40, and in particular between RK 42 and 52 (Fig. 3). 

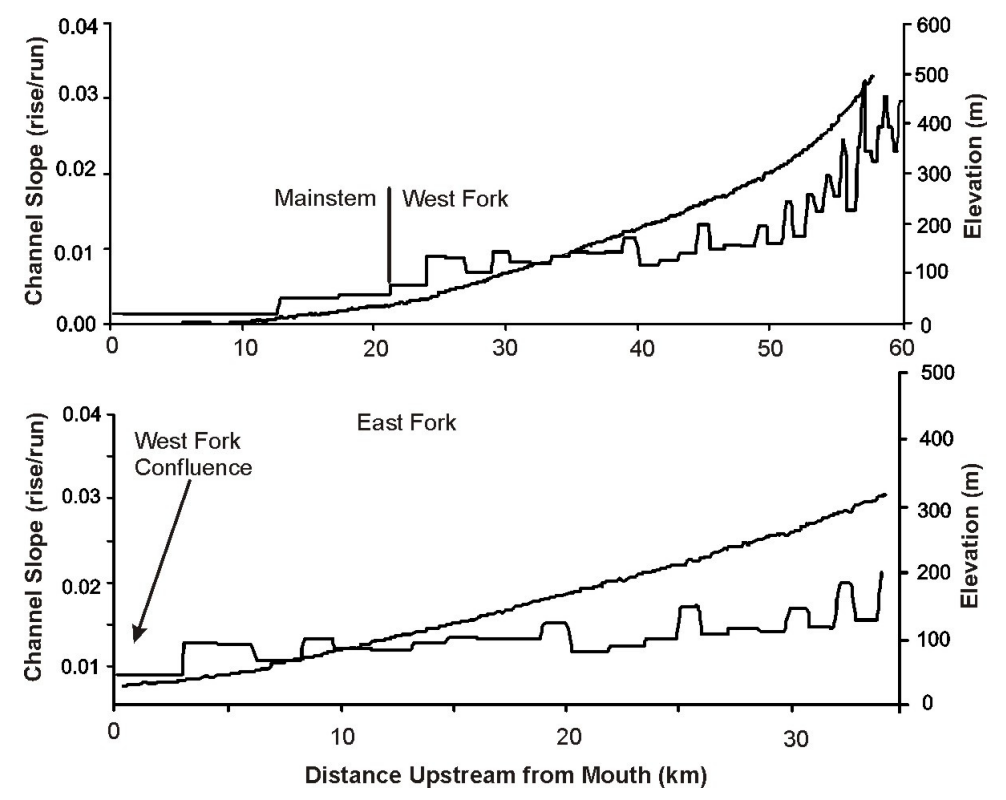

Fig. 2. The channel longitudinal profiles and the associated slope gradients (rise/run) in the "Mainstem", "West Fork" and "East Fork" channels were calculated using a 5-m digital elevation model.

An additional factor that is relevant to how network structure potentially influences the fluvial landscape is found in the longitudinal patterns of tributaries as they intersect mainstem channels. For example, the position of the West Fork within its valley between RK 25 and 40 alternates between the middle and one side or the other. Consequently, tributaries that intersect the West Fork have different energy gradients. Tributaries that intersect the West Fork near the western valley wall have higher-energy gradients and thus can transfer water, sediment, organic materials and nutrients at higher magnitudes directly to the mainstem (\# 1 and \#6 in Fig. 6), all other things being equal such as tributary basin size and erosion potential. In contrast, tributaries that intersect the West Fork after traveling over the valley floor, including paralleling the main channel, have lower energy gradients and thus may route materials to the mainstem at lower magnitudes, e.g., more temporary storage along the valley floor (Fig. 6). Higher energy tributaries that route larger magnitudes of sediment and organic material may have more pronounced and localized geomorphic effects on mainstem channels. For example, tributary \#6 (Fig. 6) that directly intersects the West Fork at the western valley wall is associated with an enlarged fluvial landscape.

\subsection{East Fork}

The East Fork drains about $200 \mathrm{~km}^{2}$ and predicted channel width and depth extends up to $22 \mathrm{~m}$ and $1.8 \mathrm{~m}$ respectively. Estimated channel gradients range from a low of about 0.01 near the confluence with the West Fork and they remain between 0.01 and 0.02 throughout the $35-\mathrm{km}$ study segment (Fig. 2).
The East Fork of the Pas River contains a different pattern of fluvial corridors compared to the West Fork. At the downstream end of the East Fork (RK 0 to 4), there is an extension of the very narrow fluvial landscape (channel bounded by a high terrace, e.g., XS-3, Fig. 5; J in Figs. 4 and 8). Upstream of that area, a broad valley $(1-1.5 \mathrm{~km}$ at RK $5-12)$ is predicted to have considerably wider fluvial landscapes $(200-800 \mathrm{~m})$, with pronounced differences between the two bankfull depth elevation bands ( $\mathrm{K}$ in Figs. 4 and 8). Immediately upstream of that area, the East Fork resides within a narrow canyon (the channel cross cuts through the same east-west trending Dolomite ridge that creates the gorge in the West Fork) with the resultant diminution of the fluvial landscape $(<50 \mathrm{~m})$ ( $\mathrm{M}$ in Figs. 4 and 8). At the upstream end of the 5-km long canyon, an abrupt increase in the width of the fluvial corridor (200-1200 m) occurs in conjunction with an intersecting tributary and a valley transition from constrained to unconstrained ( $\mathrm{N}$ in Figs. 4 and 8). Upstream of that area, the East Fork resides within a broad valley $(1 \mathrm{~km}$ wide) creating an environment for a wide fluvial corridor (200-400 m) with no significant tributary confluence influences (O in Figs. 4 and 8). However, smaller tributaries coincide within the wider fluvial landscape in this area (and run parallel to the main channel) indicating where interaction between tributaries and main channels within the fluvial landscape could occur at RK 23. The upper most East Fork then trends east-west within a narrow valley where hillslopefan/terrace landforms limit the width of the fluvial landscape to between 30 and $60 \mathrm{~m}$ (P in Fig. 4). 


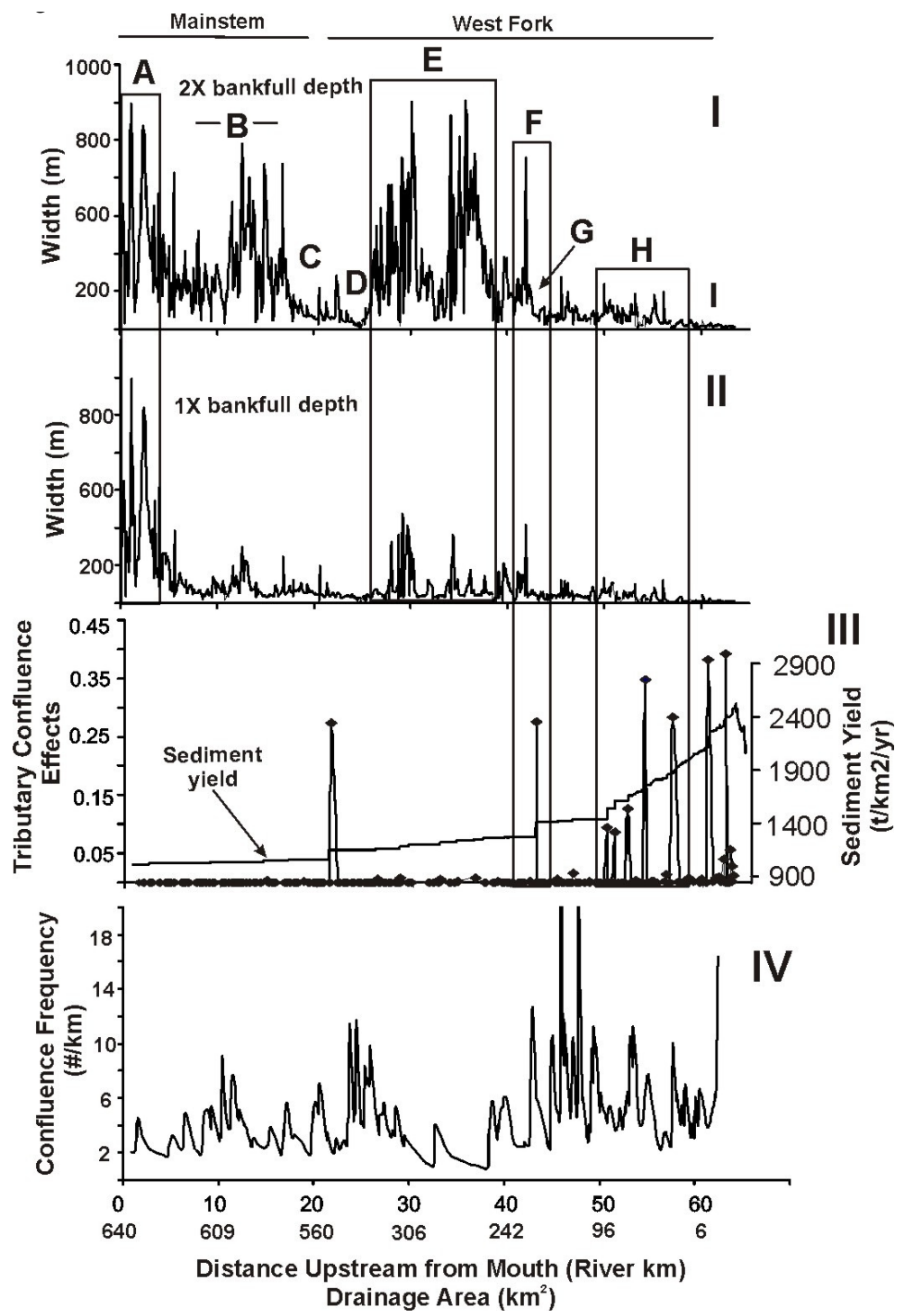

Fig. 3. The predicted fluvial landscape in the West Fork of the Pas River at an elevation above the channel equivalent to one and two bankfull depths is highly variable (I, II). The predicted tributary confluence effects and average sediment yields (using a catchment wide average of $1000 \mathrm{t} \mathrm{km}^{-2} \mathrm{yr}^{-1}$ ) are shown in (III). The spatial frequency of tributary intersections along the Mainstem and West Fork study segments shows a clumped pattern (IV). Site locations A-I are mapped in Fig. 4.

Geomorphically effective tributary confluences are predicted to be limited in the larger East Fork (drainage areas $>100 \mathrm{~km}^{2}$ ). Exceptions occur at RK 10 and RK 20-22 where larger tributaries are spatially associated with wider fluvial landscapes (K, N in Figs. 4 and 8). Although more geomorphically effective tributaries are predicted to occur in the upper East Fork catchment ( $>$ RK 25), narrow valley floors limit development of the fluvial landscape, although alternating areas of constrained and unconstrained reaches occur due to hillslope-fan/terrace forcing, similar to the upper West Fork.

There is also considerable spatial variability in the frequency of intersecting tributaries in the East Fork. The spatial frequency of confluences varies from about 2 to over ten per kilometer (Fig. 8). There are several spikes in the confluence frequency that arise due to topographic and network controls at RK 4 to 6, 15 to 18 and upstream of RK 28 (within the narrow east west trending valley).

The East Fork is located within its valley at variable positions with respect to the intersecting tributaries originating from the valley walls. The position of the East Fork alternates between the east and west side of the valleys and thus the energy gradients of the tributaries as they intersect the mainstem vary, similar to the West Fork (e.g., Fig. 6). 


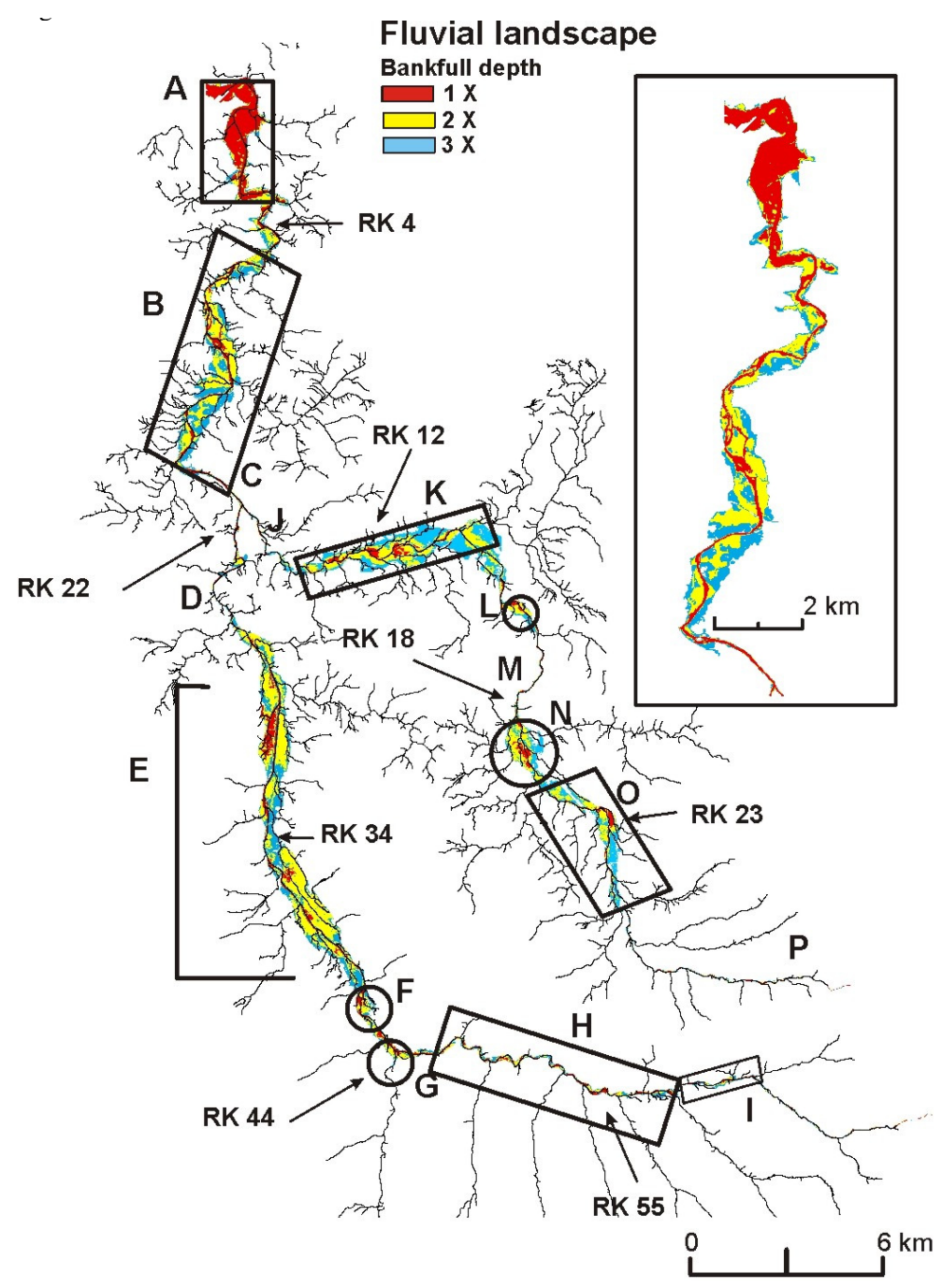

Fig. 4. The stream network (channels with gradients less than $10 \%$ ) and the predicted fluvial landscape are shown for the Pas River catchment in association with elevations above the channel equivalent to one, two and three bankfull depths. Sites A-I correspond to locations indicated in Fig. 3 and sites J through P are shown in Fig. 8. The inset box is an enlargement of the fluvial landscape in "A" and "B" and the intervening area.

\subsection{Current (2010) extent of the fluvial landscape}

Surface areas of four segments of the currently active channel and floodplain in the catchment were measured using Google Earth imagery (25 August 2010) (locations shown in Fig. 1) and compared to the topographically inferred fluvial landscape (Fig. 9). In all four areas, the currently active fluvial landscape is considerably narrower than the fluvial landscape inferred from DEM topography (Table 1). Mapped channel and floodplain areas occupy $44 \%$ to $78 \%$ (average $55 \%$ ) of the fluvial landscape that is delineated at an elevation of one bankfull depth above the channel, $11 \%$ to $25 \%$ (average $17 \%$ ) of the fluvial landscape that is delineated at two bankfull depths above the channel, and $6 \%$ to $19 \%$ (average $10 \%$ ) of the fluvial landscape delineated at three bankfull depths above the channel (Table 1). Floodplains tend to occur within two to three bankfull depths above the channel (Dunne and Leopold, 1978; Rosgen, 1996) suggesting that only $10 \%$ to $17 \%$ of the natural fluvial landscape in the Pas River catchment remains intact (Table 1).

The causes of the diminution of the present fluvial landscape include flood control dikes and levees that isolate the channel from its potentially larger fluvial landscape (e.g., XS-3 and 4 in Fig. 5). In low-lying areas protected from flooding, urban developments, farms and road networks have been built (Fig. 5, photos). Reductions in the present day fluvial landscape appear to be less in narrow valleys because of less intensive development in the form of urban centers, roads and river control structures (dikes, levees and weirs). For example, both the east-west trending valleys of the West 


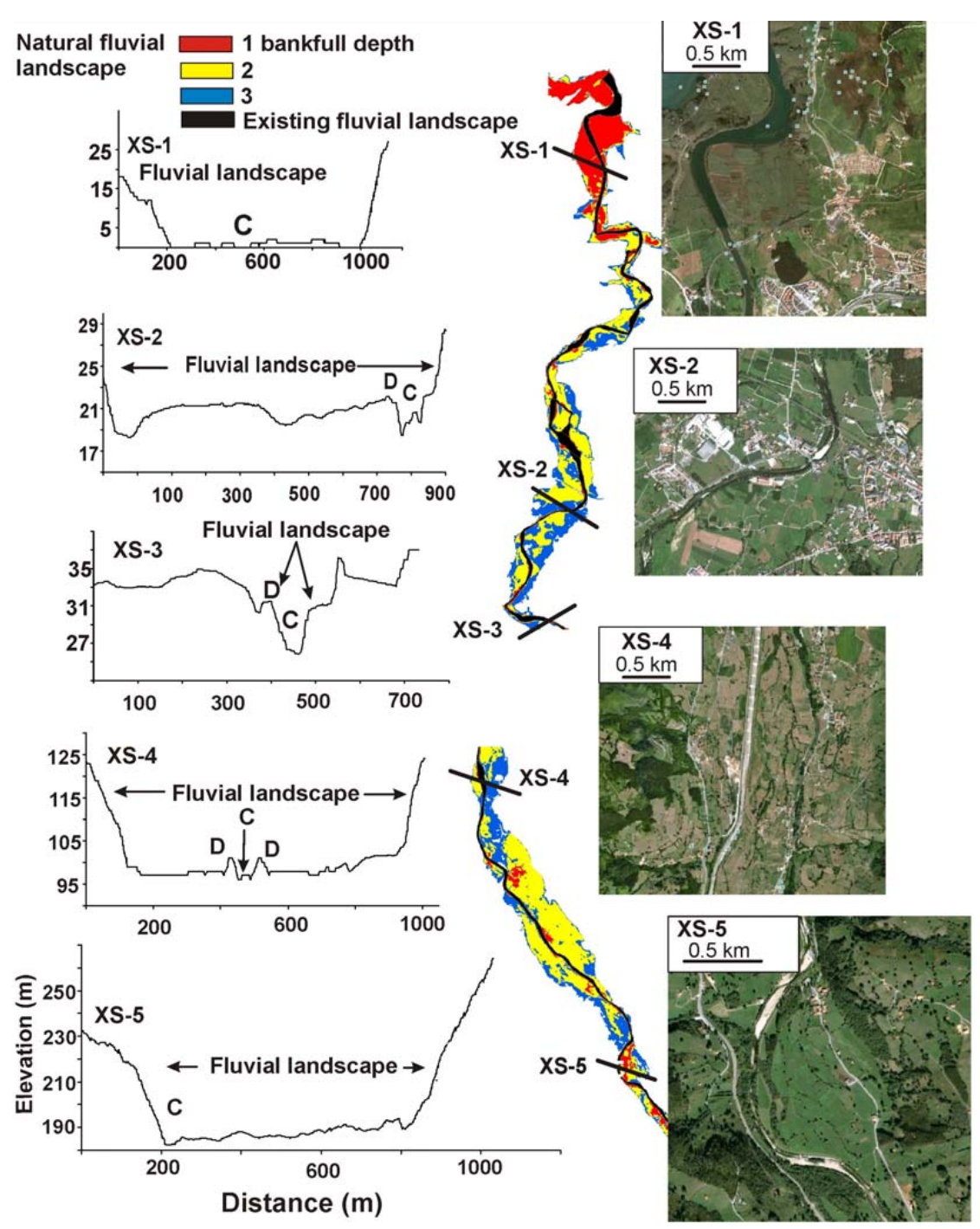

Fig. 5. Across-valley elevation profiles show the location of the predicted fluvial landscape with associated satellite images (Google Earth). The narrow, present day extent of the fluvial landscape (e.g., channel and floodplain) is denoted by "C". Elevated surfaces that are considered to be levees are denoted by "D". The fluvial landscapes depicted in the cross sections correspond to elevations associated with two bankfull depths.

and East Forks appear to have less of a reduction in the fluvial landscape but that inference could not be verified using satellite imagery alone because of dense forest cover in those areas.

\section{Discussion}

\subsection{Creating a catchment scale context for restoration planning}

In North America and Europe, river restoration planning has been evolving from the scale of individual stream reaches $(100-1000 \mathrm{~m})$ to a more expansive scale of entire catchments (Palmer et al., 2005; Bannister et al., 2005). Although restoration at the reach scale can be successful, it can also pose limitations on understanding and on project design that can lead to unsuccessful outcomes (Frissel and Nawa, 1992; Wohl et al., 2005). In Europe, the EU Water Framework Directive (EU, 2000) and EU Habitat Directive (Jähnig et al., 2010) specifically recommends creating a catchment scale context for river restoration projects. This perspective stems from an interest in returning rivers to a more natural form with improved biological productivity and diversity in those areas where it is most beneficial and feasible, even with the recognition that it will be impractical to do so in many areas because of the constraints imposed by extensive land use development, including urban centers, agriculture, and transportation systems. 


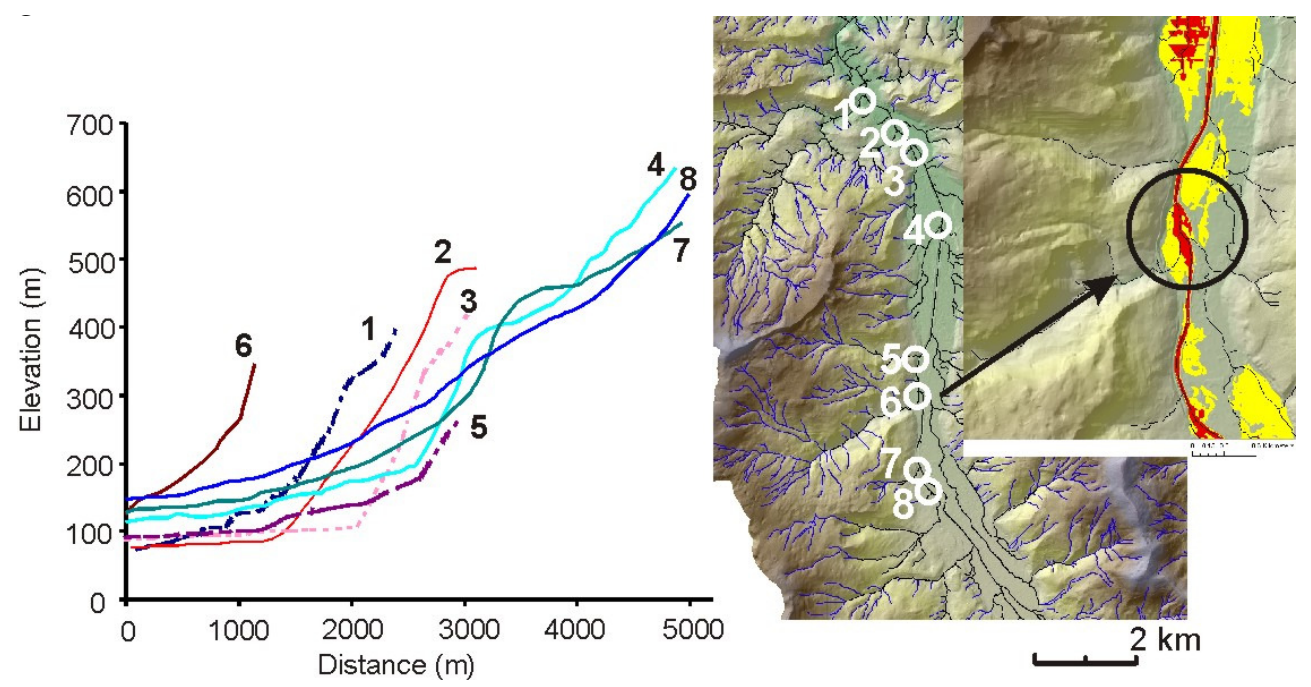

Fig. 6. Elevation (energy) gradients are shown for a select number of tributaries entering the West Fork in the wide valley (location E in Fig. 4). Tributaries 1 and 6 directly enter the mainstem and have high-energy gradients. Tributaries 2, 3, and 5 flow across the low gradient valley floor and have lower energy gradients where they intersect the West Fork. Tributaries 4, 7, and 8 are intermediate. Tributary \#6 is associated with a locally wider fluvial landscape, as depicted in the image.

Table 1. Surface area $\left(\mathrm{m}^{2}\right)$ of the present day fluvial landscape in the Pas River at four locations (Fig. 1) is compared to the predicted fluvial landscape based on one, two and three bankfull depths. Values in ( ) indicate the percent remaining based on the present day Google Map images.

\begin{tabular}{lrrrr}
\hline & $\begin{array}{c}\text { Active channel } \\
\text { surface }\left(\mathrm{m}^{2}\right)(2010)\end{array}$ & $\begin{array}{c}\text { Inundated area at } \\
\text { one bankfull }\left(\mathrm{m}^{2}\right)\end{array}$ & $\begin{array}{r}\text { Inundated area at } \\
\text { two bankfull }\left(\mathrm{m}^{2}\right)\end{array}$ & $\begin{array}{r}\text { Inundated area at } \\
\text { three bankfull }\left(\mathrm{m}^{2}\right)\end{array}$ \\
\hline $\begin{array}{l}\text { Northern west } \\
\text { fork (\#1) }\end{array}$ & 1781034 & $3727575(47 \%)$ & $6897882(25 \%)$ & $9399339(19 \%)$ \\
$\begin{array}{l}\text { Upper East } \\
\text { Fork (\#4) }\end{array}$ & 424341 & $5418171(78 \%)$ & $2154313(19 \%)$ & $5148263(8 \%)$ \\
$\begin{array}{l}\text { Lower East } \\
\text { Fork (\#3) }\end{array}$ & 200288 & $449829(44 \%)$ & $1846184(11 \%)$ & $3278370(6 \%)$ \\
West Fork (\#2) & 707464 & $1297463(54 \%)$ & $5285891(13 \%)$ & $7546984(9 \%)$ \\
\hline Average & & $(55 \%)$ & $(17 \%)$ & $(10 \%)$ \\
\hline
\end{tabular}

The key to creating a catchment scale context for river restoration will be establishing a "guiding ecological image" (Palmer et al., 2005) also referred to as a "geomorphic template" (Brierly et al., 2008). This is challenging because it will require an analysis of the entire catchment of interest, highlighting the spatial and temporal characteristics of the fluvial landscape that govern geomorphic and ecosystem interactions (Kondolf, 2000). However, more often than not, morphological patterns indicative of a well functioning fluvial landscape have been obscured or eliminated by flow regulation by dams and weirs, construction of flood control levees and dikes, hardening of banks, filling in of side channels and wetlands, and building on floodplains.

Reconstructing the fluvial landscape in catchments where past land uses have obscured it has been successful, particularly in areas where historical aerial photographs support mapping of pre-development floodplains, side channels, beaver dams and log jams (Collins et al., 2003). However, reconstructing the natural fluvial landscape in catchments with a multi-century history of land use can be more difficult, particularly in areas where historical photos and other evidence are not readily available.

In large catchments, such as the Pas River $\left(650 \mathrm{~km}^{2}\right)$ where extensive land use has eliminated or partly obscured the natural fluvial landscape, efficient approaches will be needed to create the types of maps and databases necessary to underpin catchment scale planning in river restoration. In this paper, our approach takes advantage of recent advances in the science of fluvial landscapes and computer based analysis tools. However, because of its reliance on 


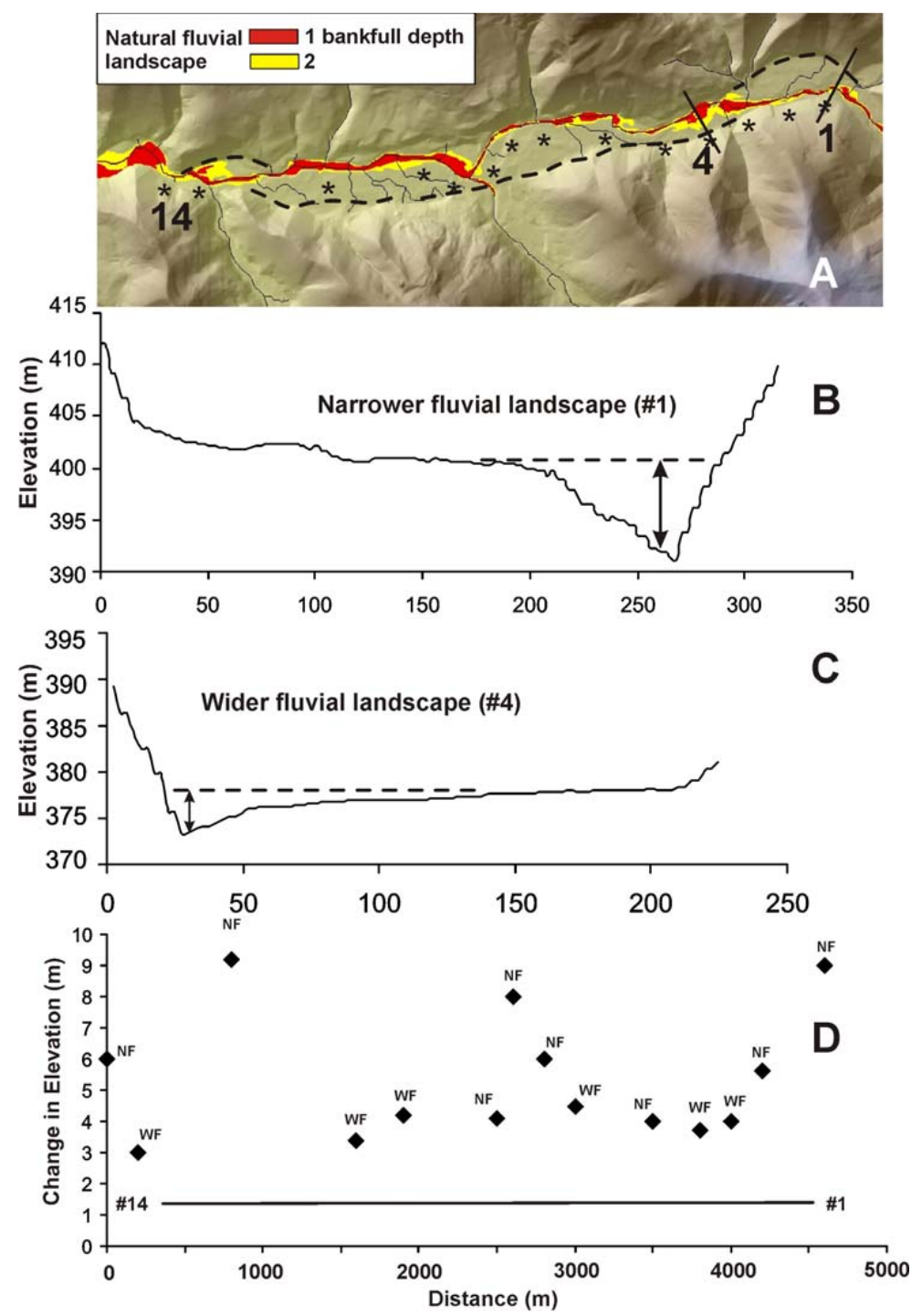

Fig. 7. The narrow east-west trending valley in the upper West Fork (H, Fig. 4) contains terrace and fan deposits that create alternating wide and narrow fluvial landscapes (A). In the lower panel (D), the change in elevation corresponds to the elevation difference between the channel and bounding landforms, as illustrated in (B) and (C); NF and WF indicates "narrow fluvial landscape and "wider fluvial landscape, respectively". "*” on the upper panel denotes locations of the cross sections 1 through 14 , from right to left.

remote sensing, field surveys would be required to verify many of the inferences that are drawn and to create the necessary context for smaller scale restoration projects.

A guiding ecological image or geomorphic template for river restoration at the catchment scale can be considered at different levels of detail. In a natural history context, one can consider the processes and patterns of the fluvial landscape with the aim of better understanding fluvial landform development. On a more applied level, a catchment scale perspective can be used to identify candidates for restoration.

\subsection{Natural history of the Pas River fluvial landscape}

The spatial patterns inferred from DEM analysis in the Pas river system reflect unique geological and geomorphological catchment controls on the fluvial landscape. At a broad scale, the width of the fluvial landscape generally increases downstream as channels, and the valleys they flow through, become larger and attain lower channel gradients (Figs. 2, 3 and 8 ). There is, however, considerable spatial variability in the width and geometry of the fluvial landscape due to topographic and river network controls.

The largest (in width) and potentially the most complex fluvial landscapes in the Pas River catchment likely coincide with specific geologic structures. For example, the N-S 


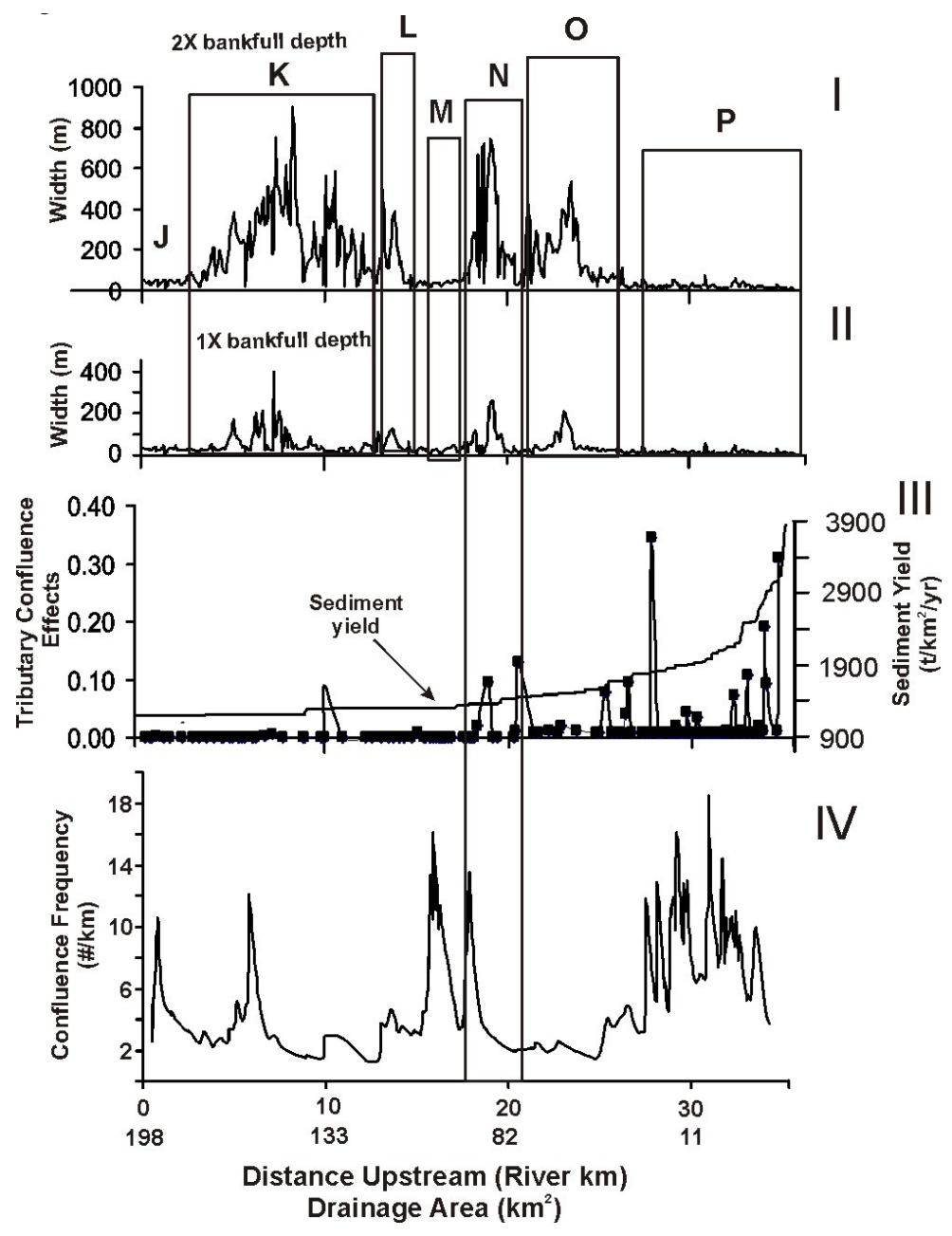

Fig. 8. The predicted fluvial landscape in the East Fork of the Pas River at an elevation above the channel equivalent to one and two bankfull depths is highly variable (I, II). The predicted tributary confluence effects and average sediment yields (using a catchment wide average of $1000 \mathrm{t} \mathrm{km}^{-2} \mathrm{yr}^{-1}$ ) are shown in (III). The spatial frequency of tributary intersections along the East Fork reveals a clumped pattern (IV). Site locations J-P are mapped in Fig. 4.

trending valley on the West Fork parallels the strike of an anticline (IGME, 1989), which may have contributed to its broad geometry and low gradients. A similar broad valley in the East Fork at the same latitude suggests an analogous geological control. The broad east-west trending valley in the lower East Fork coincides with several major faults, suggesting a structural origin for this wide and low gradient valley as well. Both the West and East Forks follow narrow canyons cut through an east-west trending Dolomite ridge. The fluvial landscape through these canyon reaches is very constrained and narrow, with the exception of one small area at the downstream end of the East Fork canyon.

The various shapes of the catchment subbasins and the associated river network structure dictate the potential role of confluences in influencing the dimensions and function of the fluvial landscapes. Overall, within the larger fluvial landscape of the Pas River catchment, tributary effects are predicted to be modest; each of the sub-basins are relatively narrow and tributary channels have small drainage areas relative to the trunk streams. However, within the larger channels of the West and East Forks, there are several locations where confluences may be associated with wider fluvial landscapes (F, G in Figs. 3 and 4; $\mathrm{K}, \mathrm{N}$ in Figs. 4 and 8). Although relatively large tributaries may be needed to create large geomorphic effects in receiving rivers (tributary area/mainstem area $>0.3$, Benda et al., 2004b), even small tributary confluences can serve as important ecological nodes because they can act as migration corridors, micro habitats, thermal refugia, and sources of nutrients (Rice et al., 2008; Eros et al., 2011).

In contrast to wider valleys, the east-west trending West Fork is asymmetrically located within its basin with numerous large tributaries intersecting the valley from the south (Fig. 1). This factor, in addition to predicted 


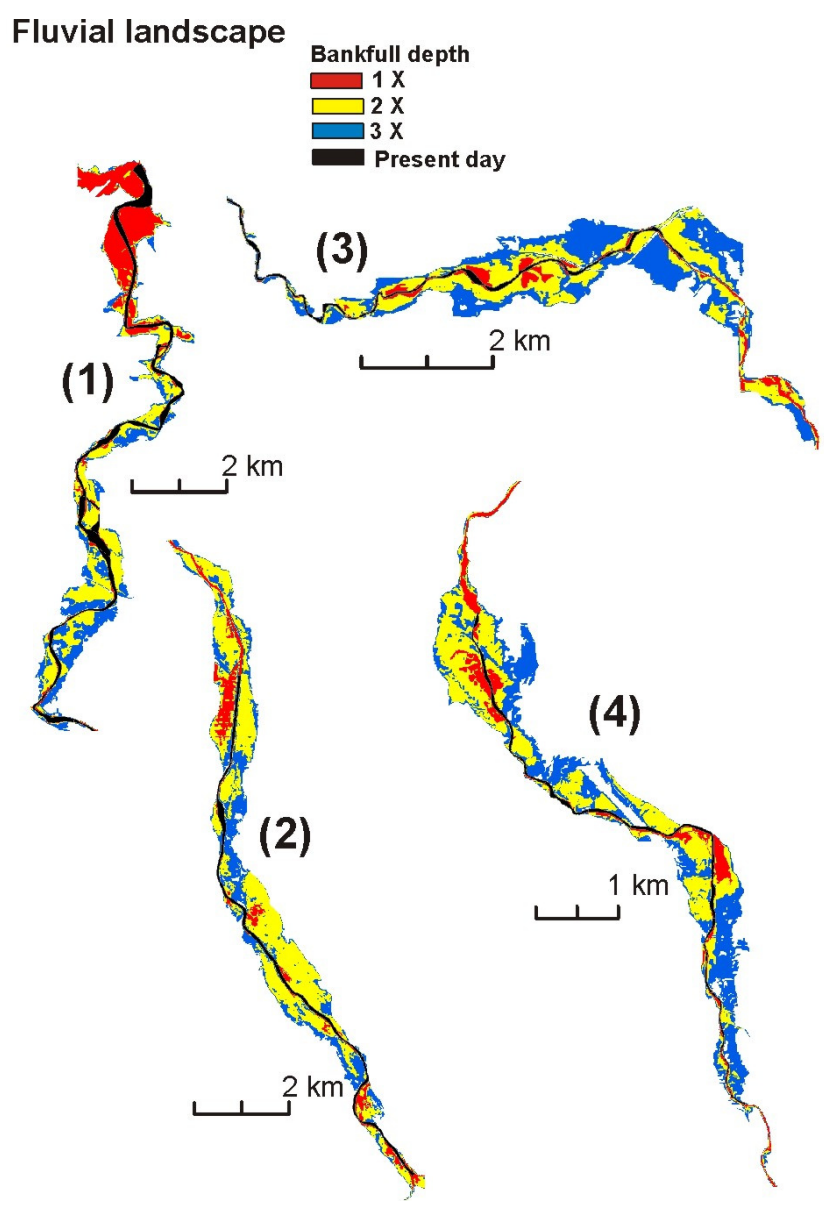

Fig. 9. The present day extent of the fluvial landscape along four segments of the Pas River (Fig. 2) was mapped using satellite imagery (Google Earth, 2010). The predicted fluvial landscape using one, two and three bankfull depths above the channel are shown for comparison. The present day fluvial landscape is approximately $10 \%$ to $17 \%$ of the predicted fluvial landscape using two and three bankfull depths (Table 1).

high sediment yields and a narrow valley floor, promotes hillslope-fan/terrace forcing of the fluvial landscape. The terrace-fan landforms bound the active channel and the resultant fluvial corridor ranges in width between 50 and $200 \mathrm{~m}$ on one or both sides of the channel throughout the $10-\mathrm{km}$ long segment. Through this reach, unconstrained valley segments occur where elevation differences between channels and terraces are less than $4 \mathrm{~m}$ and constrained segments are bounded by landforms 4 to $9 \mathrm{~m}$ high (Fig. 7). These alternating constrained and unconstrained reaches could be considered a "string of pearls" (Ward et al., 2002) that likely contributes to physical heterogeneity through this portion of the river corridor.

Although the broad N-S trending valleys in the West and East fork contain relatively minor tributaries, several of them run parallel to the mainstem. This can increase the potential for ecological complexity, because the floodplains of the two fluvial systems can overlap and there is greater opportunity for hyporheic exchange. In addition, the spatial frequency of confluences (of tributaries of any size) is highly variable along all of the study segments, ranging from 2 to 20 per kilometer (Figs. 3 and 8). The zones of highest confluence frequency tend to be localized and areas of higher numbers of tributary intersections could be considered to have high ecological potential in the context of restoration. The patterns of confluences and tributaries that occur away from the mainstream also have important ecological implications (Eros et al., 2011).

Natural disturbances in the form of floods, fires and windstorms are key factors that create and rejuvenate the natural fluvial landscape. In particular, large floods form and maintain floodplains (when floods are not controlled by in-stream structures) and erosion processes including landslides, gullies and surface erosion contribute to the punctuated supply of sediment that creates numerous aspects of the fluvial landscape, including tributary confluence effects and variable and complex channel morphologies. Although the mapping of the dynamic components of the fluvial landscape in the Pas River catchment is beyond the scope of the paper, aspects of catchment dynamics can be inferred from some of the spatial patterns shown in the figures.

\subsection{Identifying candidate sites for restoration}

Comparing the current extent of active channels and floodplains with the topographically delineated fluvial landscape reveals that perhaps only $10 \%$ to $15 \%$ of the original fluvial landscape remains active in the Pas River catchment. Nevertheless, even in controlled riverine environments, it may be feasible to reestablish a functioning channel-floodplain ecosystem, at least incrementally in certain areas (Logan and Furze, 2002; Gilvear and Casas, 2008). A catchmentscale perspective of the natural fluvial landscape as described herein can provide an important context from which to plan, design, and carry out restoration projects.

Restoration planning could focus on specific zones in the Pas River catchment, local areas ( 0.5 to $5 \mathrm{~km}$ long, 0.1 to 1 or more $\mathrm{km}^{2}$ ) that have the qualifying physical characteristics to create favorable riverine environments (through restoration) that include: (1) lower gradient channels with wide floodplains, (2) significant tributary confluences, (3) high density of confluences, (4) valley transitions, (5) proximity to sources of sediment and organic material, and (6) closely aligned, parallel running tributary-mainstem channels. The candidate sites listed below are grouped into four fluvial landform domains and they all have three or more of the qualifying characteristics. The sites described briefly below are at the network scale due to the remote sensing dependence of this study. In practical terms, restoration planning and project design will be carried out at smaller reach scales and restoration activities could involve reconnecting channels with a more extensive fluvial ecosystem 


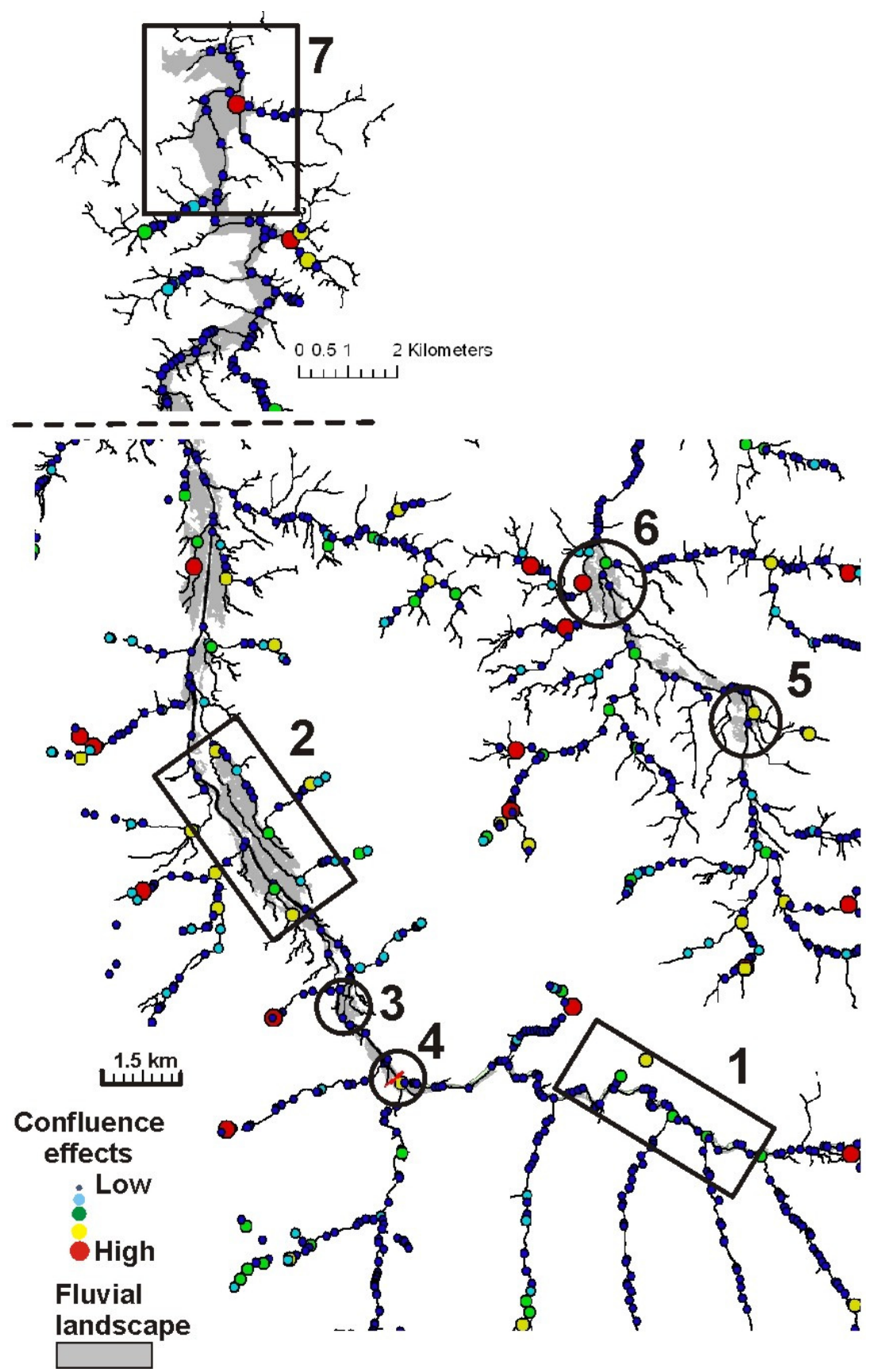

Fig. 10. The analysis of fluvial landscapes in the Pas River network provides a catchment scale context for restoration planning. Four types of fluvial landscapes are identified: (A) narrow valleys-string of pearls (\#1), (B) broad valleys-complex floodplains (\#2), (C) confluence related areas and valley transitions (\#3, 4, 5 and 6), and (D) lower riverine-estuarine environments (\#7). Not all sites that fall into these categories are shown. The shaded reconstructed riverine landscape denotes areas located within one and two bankfull depths.

1. Narrow valleys - string of pearls: in both the upper West and East Forks, hillslope-fan/terrace forcing has created a sequence of alternating wide and narrow fluvial landscapes (Fig. 7). In the upper basins, human encroachment on the channel-floodplain complex appears to be limited due to the lower densities of roads and dwellings, although a few urban centers exist. Restoration here could target the wide corridor segments, the fluvial landscape "pearls" (G through $\mathrm{H}$ in Fig. 4; "\#1 in Fig. 10 and E in Fig. 11). Field surveys could examine the degree to which bank protection (dikes), roads, and other structures restrict channel-floodplain interactions 

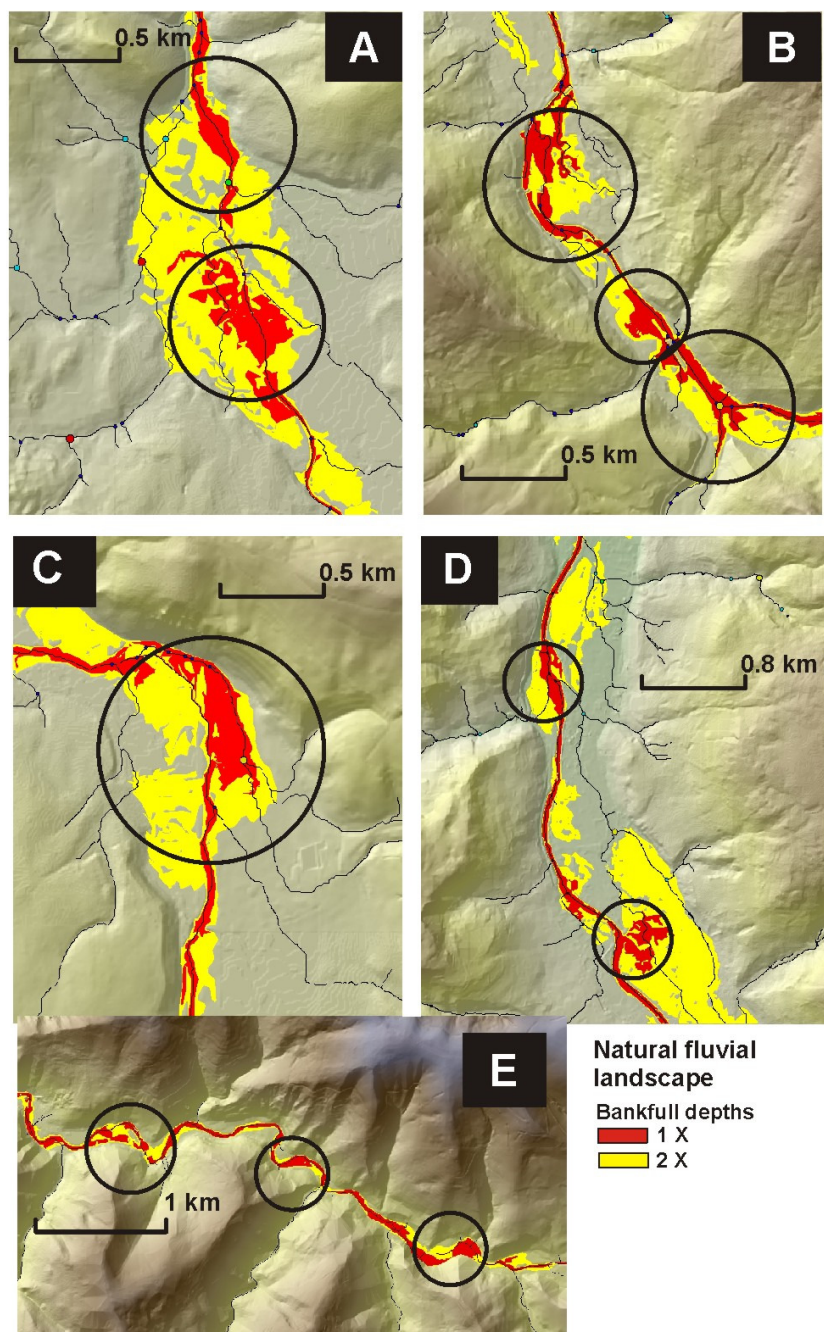

Fig. 11. A sample of close up images is shown of the predicted fluvial landscape at potential restoration areas: (A) an enlarged fluvial landscape located at the transition from an unconfined to a confined valley in combination with a large tributary confluence ( $\mathrm{N}$ in Figs. 4 and 8, \#6 in Fig. 10); (B) individual fluvial landscapes that have high potential for lateral connectivity are located at the site of a large meander and at a significant tributary confluence (F, G, Figs. 3 and 4, \#3 and 4 in Fig. 10); (C) an area within the East Fork basin where a channel interacting with hillslope creates a large meander, in combination with a high density of parallel running tributaries, could denote a potentially productive and complex fluvial landscape (\#5 in Fig. 10); (D) areas within the wide valley of the West Fork, one of which may be influenced by a confluence (E, Figs. 3 and 4); and (E) the upper West Fork segment where hillslope/fan forcing has created alternating wide and narrow fluvial landscapes ( $\mathrm{H}$ in Fig. 4, \#1 in Fig. 10).

through the wide sections, and identify those sites where restoration activities could enhance the coupling between aquatic and riparian systems. Restoring areas in close proximity to one another and in areas near confluences could be an effective restoration strategy to restore ecological connectivity.

2. Broad valleys - complex floodplains: the widest inferred fluvial corridors in the Pas catchment lie in broad, low gradient valleys between RK 25-40 in the West Fork, between RK 4-12 and RK 18-25 in the East Fork, and between RK 2-15 in the Mainstem (A, B, E, K, N, $\mathrm{O}$ in Figs. 3, 4 and 8). In the absence of human alterations, these areas likely exhibited extensive lateral connectivity among channels, floodplains, and riparian areas. Major tributary confluences do not exist within most of the broad valleys (an exception being Site $\mathrm{N}$ in the East Fork at RK 18-20). However, the frequency of intersection of tributaries of all sizes is highly variable (2-20 km, Figs. 3 and 8), and zones of high frequencies could be viewed in the context of the wider fluvial landscapes in the broad valleys to locate restoration candidates (e.g., \#2 in Fig. 10 and A in Fig. 11). Individual, high energy tributaries may also drive locally wider fluvial landscapes at confluence intersections (Fig. 6). Moreover, tributary channels that run parallel to mainstem channels can contribute to floodplains, wetlands, and hyporheic flow. In such broadvalley environments, tributary spacing and orientation may be important, because tributary intersections function as key dispersal corridors for aquatic and riparian plant and animal species (Eros et al., 2011).

Because of the multiple processes active in broad, lowgradient fluvial zones, these fluvial landscapes probably constituted the most diverse riverine environments in the Pas catchment prior to pervasive human development, and therefore pose the highest potential for restoring diversity in the riverine ecosystem. Areas within these zones with the least human development (e.g., E and $\mathrm{O}$ in Fig. 4 and see XS-4 photo, Fig. 5) can therefore pose exceptional targets for restoration of combined mainstem-tributary environments (\#2 in Fig. 10; A, C in Fig. 11). Throughout most of these areas, the diminution of the fluvial landscape has been generally universal and to a similar extent. However, field studies would be required to validate the provisional findings presented here and to provide additional smaller scale, site-specific information on restoration opportunities.

Similar geomorphic settings in other broad valleys (B, K, Fig. 4 and see XS-2 photos, Fig. 5) have more extensive urban development that may be less conducive to restoration activities.

3. Confluence Related Areas and Valley Transitions There are numerous tributary confluence related zones that could be highlighted for restoration because of their potential for creating ecologically diverse and productive areas (for a comprehensive review of the geomorphic and ecologic effects of confluences see Benda et al., 
2004a, b and Rice et al., 2008). Four candidate sites are listed below and analysts could identify others by examining the maps and graphical data in this paper. Site F in the West Fork at RK 42 (Fig. 4) is located in a wide fluvial landscape located downstream and in close proximity to a large sediment-producing tributary (see XS-5 photo, Fig. 5; \#3 in Fig. 10). Another area is in the East Fork at RK 22 (Fig. 4) where several small tributaries that originate from the eastern side of the valley and merge onto a wide fluvial landscape and run parallel to the mainstem channel (\#5 in Fig. 10; $\mathrm{C}$ in Fig. 11). Individual large tributaries can have a significant local impact on the development of fluvial landscapes. One is located where the West Fork turns from north-south to east-west (RK 44, Fig. 3). The large intersecting tributary is associated with a local increase in the width of the fluvial corridor ( $\mathrm{G}$ in Fig. 4; \#4 in Fig. 10). Areas where tributaries intersect valley transitions could present very unique geomorphological and hence ecological settings, and could be highlighted in a catchment scale context for restoration. For example, in the East Fork at RK 18-20 a large tributary intersects the truck stream at the upstream transition from an unconstrained to a constrained valley segment (N, Figs. 4 and 8; \#6 in Fig. 10; A in Fig. 11). Other areas could be identified that focus on the spatial frequency of tributary confluence intersections (e.g., Figs. 3 and 8, lower panel).

4. Lower Riverine-Estuarine Environments: the interaction of fluvial and tidal processes creates a unique, diverse, and highly productive environment that includes fluvial, near shore, subtidal, and estuarine habitats (\#7 in Fig. 10). In the Pas River system, this zone occupies the widest, lowest relief fluvial corridor (A in Figs. 3 and 4). The mixed fluvial-estuarine environment may represent one of the most valuable ecosystems to restore, but also the most challenging, given the presence of urban centers and transportation systems (XS-1 photo, Fig. 5).

Whether the candidate fluvial landscapes described above present restoration opportunities will require a planning process that focuses on desired ecological outcomes as well as field evaluation of relevant geomorphic and ecological criteria (Mika et al., 2010). In addition, analysis of restoration opportunities must consider socio-economic constraints, a topic beyond the scope of this paper. At a minimum, restoration activities would be constrained by land use and ownership, such as urban versus agricultural areas. A catchment scale context for restoration planning could enhance existing restoration programs in the Pas River catchment (Pas Water Authority). Restoration efforts aimed at reconnecting channels with their larger fluvial landscape should also contain a monitoring component (Pasquale et al., 2011).

There are undoubtedly other types and locations of restoration opportunities based on the landscape interpretation presented in this paper, limited only by imagination, training, experience and field work.

\section{Conclusions}

In this paper we present a new and innovative approach for creating a catchment scale perspective for river restoration planning. We combined new computer tools (NetMap, www.netmaptools.org, Benda et al., 2007, 2009) with high resolution digital elevation data to evaluate the network scale structure of fluvial landscapes in the Pas River catchment in northern Spain. Our analysis focused on five hydrogeomorphic landform domains including (1) hillslope and valley topography, (2) river network structure involving tributary confluences and material flux, (3) channel elevation profiles, (4) hillslope-fan/terrace landforms and (5) mixed estuarine-fluvial environments. Valley floor surfaces were mapped according to elevation above the channel and proximity to key hydro-geomorphic landforms. The predicted natural fluvial landscape (containing channels, floodplains, off channel water bodies, wetlands and terraces) is spatially patchy and organized by catchment topography, river network structure, basin scale and fan and terrace landforms.

The present day fluvial landscape is constrained by numerous engineered structures (dikes, dams, levees, roads). Comparing the existing fluvial landscape with the predicted fluvial landscape indicates that about $10 \%$ to $15 \%$ of the natural fluvial landscape remains in the Pas River catchment.

Our analysis was used to identify provisional candidate sites for restoration that would contain some combination of wide floodplains, significant tributary confluences, high density of confluences, valley transitions, proximity to sources of sediment and organic material, and closely aligned, parallel running tributary-mainstem channels. Our illustrative set of candidate restoration sites are grouped into four landform domains: (1) narrow valley-string of pearls, (2) broad valleys-complex floodplains, (3) confluence related areas and valley transitions, and (4) lower riverine-estuarine environments. Because of the remote sensed aspect of this illustrative study, field validation is required to check computer based predictions of the natural fluvial landscape as well as the potential for future restoration activities.

Acknowledgements. This project was funded by the MARCE project (Ref: CTM-2009-07447) at the University of Cantabria, Sandander Spain and Earth Systems Institute, Seattle, Washington and Mt. Shasta, California USA.

Edited by: E. Mitchell 


\section{References}

Alcala-Zamora, J. and Quiepo De Llano, J.: Historia de una empresa siderúrgica española: Los Altos Hornos de Liérganes y La Cavada, 1622-1834, Santander: Consejería de Cultura, Turismo y Deporte/Estudio, 2004.

Álvarez-Cabria, M., Barquín, J., and Juanes, J. A.: Macroinvertebrate community dynamics in a temperate European Atlantic river, Do they conform to general ecological theory?, Hydrobiologia, 658, 277-291, 2011.

Bannister, N., Mant, J., and Janes, M.: A review of catchment scale river restoration projects in the UK, Report by the River Restoration Center; Sponsored by the Environmental Agency, 48pp., 2005.

Barquín, J., Ondiviela, B., Recio, M., Álvarez-Cabria, M., Peñas, F. J., Fernández, D., Gómez, A., Álvarez, C., and Juanes, J. A.: Assessing the conservation status of alder-ash alluvial forest and Atlantic salmon in the Natura 2000 river network of Cantabria, Northern Spain, in: River conservation and management: 20 years on, edited by: Boon, P. J. and Raven, P. J., WileyBlackwell, in press, 2011.

Baxter, C. V.: Fish movement and assemblage dynamics in a $\mathrm{Pa}$ cific Northwest Riverscape. Doctoral Dissertation, Oregon State University, Corvallis, OR, 298 pp, 2001.

Benda, L. and Dunne, T.: Stochastic forcing of sediment supply to channel networks from landsliding and debris flow, Water Resour. Res. 33, 2849-2863, 1997a.

Benda, L. and Dunne, T.: Stochastic forcing of sediment routing and storage in channel networks, Water Resour. Res., 33, 28652880, $1997 \mathrm{~b}$.

Benda, L., Miller, D. J., Dunne, T., Reeves, G. H., and Agee, J. K.: Dynamic Landscape Systems, Pages 261-288, in: River Ecology and Management, edited by: Naiman, R. J. and Bilby, R. E., Springer-Verlag, New York, 1998.

Benda, L., Miller, D. J., Dunne, T., Poff, L., Reeves, G., Pollock, M., and Pess, G.: Network dynamics hypothesis: spatial and temporal organization of physical heterogeneity in rivers, BioScience, 54, 413-427, 2004a.

Benda, L., Andras, K., and Miller, D.: Tributary effects in river networks: role of basin scale, basin shape, network geometry, and disturbance regimes, Water Resour. Res., 40, 1-15, 2004b.

Benda, L., Miller, D. J., Andras, K., Bigelow, P., Reeves, G., and Michael, D.: NetMap: A new tool in support of watershed science and resource management, Forest Sci., 52, 206-219, 2007.

Benda, L., Miller, D., Lanigan, S., and. Reeves, G.: Future of applied watershed science at regional scales, EOS, Transaction American Geophysical Union, 90, 156-157, 2009.

Best, J. L.: Sediment transport and bed morphology at river channel confluences, Sedimentology, 35, 481-498, 1988.

Bigelow, P., Benda, L., Miller, D. J., and Burnett, K. M.: On debris flows, river networks, and the spatial structure of channel morphology, Forest Sci., 52, 220-238, 2007.

Brierley, G., Fryirs, K., Boulton, A., and Cullum, C.: Working with change: the importance of evolutionary perspectives in framing the trajectory of river adjustment, Pages 65-84, in: River Futures: An Integrative Scientific Approach to River Repair, edited by: Brierley, G. and Fryirs, K., Island Press, Washington, D.C., USA, 2008.
Castro, J. M.: Stream classification in the Pacific Northwest: methodologies, regional analyses and applications, PhD. Dissertation, Oregon State University, 104 pp., 1997.

Cerdá, A.: La erosion del suelo y sus tasas en Espana, Ecosistemas, Ano X, No. 3, 2001.

Church, M.: Pattern of instability in a wandering gravel bed channel. Pages 169-180, in: Modern and ancient fluvial systems, edited by: Collinson, J. D. and Lewin, J., Blackwell, Oxford, 1983.

Clarke, S., Burnett, K. M., and Miller, D. J.: Modeling streams and hydrogeomorphic attributes in Oregon from digital and field data, Journal of American Water Resources Association, 44, 459-477, 2008.

Collins, B. D., Montgomery, D. R., and Shiekh, A. J.: Reconstructing the historic riverine landscape of the Puget Sound, Pages 79128, in: Restoration of Puget Sound Rivers, edited by: Montgomery, D. R., Bolton, S., Booth, D. B., and Wall, L., University of Washington Press, Seattle, 2003.

Costas, N., ÁLvarez, M., and Pardo, I.: Characterization of an Atlantic salmon Salmo salar stream at the southern limit of its eastern Atlantic distribution, J. Fish Biol., 75, 2552-2570, 2009.

Delgado Vinas, C.: Los montes de Pas: Realidad, presente y expectativas de futuro. Servicio de Publicaciones de la Universidad de Cantabria, Santander, Cantabria, Espana, ISBN 84-8102-342-6, 2003.

Dietrich, W. E. and Dunne, T.: Sediment budget for a small catchment in mountainous terrain, Zietshrift fur Geomorphologie, 191-206, 1978.

Doadrio, I.: Atlas y libro rojo de los peces continentals de Espana, Direccion General de Conservacion de la Naturalcza, Madrid, 364 pp., 2001.

Dunne, T. and Leopold, L. B.: Water in Environmental Planning. W. H. Freeman and Company, New York, 818 pp., 1978.

Edwards, R. T.: The hyporheic zone, Pages 399-429, in: River ecology and management: lessons from the Pacific coastal ecosystem, edited by: Naiman, R. and Bilby, R. E., Springer, New York, 1998.

Eros, T., Schmera, D., and Schick, R. S.: Network thinking in riverscape conservation - a graph based approach, Biol. Conserv., 144, 184-192, 2011.

EU Directive: 2000/60/EC of the European Parliament and of the Council of 23 October 2000 establishing a framework for Community action in the field of water policy, 2000.

Fausch, K. D., Torgersen, C. E., Baxter, C. V., and Li, H.: Landscapes to riverscapes: Bridging the gap between research and conservation of stream fishes, Bioscience, 52, 483-498, 2002.

Frissell, C. A. and Nawa, R. K.: Incidence and Causes of Physical Failure of Artificial Habitat Structures in Streams of Western Oregon and Washington (Bigelow), N. Am. J. Fish. Manage., 12, 182-197, 1992.

GESHA: Plan de investigación integral para la caracterización y diagnóstico ambiental de los sistemas acuáticos de la Comunidad de Cantabria, Consejería de Medio Ambiente, Gobierno de Cantabria, Santander, 2005a.

GESHA: Estudio de los recursos hídricos de los ríos de la vertiente norte de Cantabria, Consejería de Medio Ambiente, Gobierno de Cantabria, Santander, 2005b. 
Gilvear, D. and Casas, R.: River restoration at the catchment scale in Scotland: current status and opportunities, Final Report, Center for River Ecosystem Science, University of Stirling, Stirling Scotland, 73 pp., 2008.

Grant, G. G. and Swanson, F. J.: Morphology and processes of valley floors in mountain streams, Western Cascades, Oregon, Pages 83-101, in: Natural and Anthropogenic Influences in Fluvial Geomorphology, edited by: Costa, J. E., Miller, A. J., Potter, K. W., and Wilcock, P. R., Geophysical Monograph, 89, American Geophysical Union, Washington, D. C., 1995.

IGME: Mapa Geologico de Cantabria a escala 1:100.000, Información geocientífica del Instituto Geologico y Minero Espanol, Madrid, 1989.

Jähnig, S. C., Brabec, K., Buffagni, A., Erba, S., Lorenz, A. W., Ofenböck, T., Verdonschot, P. F. M., and Hering, D.: A comparative analysis of restoration measures and their effects on hydromorphology and benthic invertebrates in 26 central and southern European rivers, J. Appl. Ecol., 47, 671-680, 2010.

Kiffney, P. M., Greene, C., Hall, J. M., and Davies, J.: Gradients in habitat heterogeneity, productivity, and diversity at tributary junctions, Can. J. Fish. Aquat. Sci., 63, 2518-2530, 2006.

Kondolf, G. M.: Process vs form in restoration of rivers and streams, in: Annual Meeting Proceedings of the American Society of Landscape Architects, edited by: Scheu, D. L., St. Louis, MO (pp. 120-124), American Society of Landscape Architects, Washington D.C., 2000.

Kondolf, G. M., Anderson, S., Lave, R., Pagano, L., Merenlender, A., and Bernhardt, E. S.: Two Decades of River Restoration in California: What Can We Learn?, Restor. Ecol., 15, 516-523, 2007.

Lara, F., Garilleti, R., and Calleja, J. A.: La vegetacion de ribera de la mitad norte Espanola, Cedex, Mongrafias, 81, Madrid, 536 pp., 2004.

Logan, P. and Furze, M.: Preparing for the European Water Framework Directive - making the links between habitat and aquatic biota, Aquatic Conservation, 12, 425-437, 2002.

Mika, S., Hoyle, J., Kyle, G., Howell, T., Wolfenden, B., Ryder, D., Keating, D., Boulton, A., Brierley, G., Brooks, A. P., Fryirs, K., Leishman, M., Sanders, M., Arthington, A., Creese, R., Dahm, M., Miller, C., Pusey, B., and Spink, A.: Inside the "black box" of river restoration: using catchment history to identify disturbance and response mechanisms to set targets for process-based restoration, Ecol. Soc., 15, p.8, 2010.

Miller, D. J. and Burnett, K. M.: Effects of forest cover, topography, and sampling extent on the measured density of shallow, translational landslides, Water Resour. Res., 43, 1-23, 2007.

Montgomery, D. R. and Buffington, J. M.: Channel-reach morphology in mountain drainage basins, Geol. Soc. Am. Bull., 106, 596-611, 1997.

McDowell, P. F.: Spatial Variations in Channel Morphology at Segment and Reach Scales, Middle Fork John Day River, Northeastern Oregon, Pages 159-172, in: Geomorphic Processes and Riverine Habitat, edited by: Dorava, J. M., Montgomery, D. R., Palcsak, B. B., and Fitzpatrick, F. A., American Geophysical Union, Washington, D.C., 2001.

Naiman, R. J., Beechie, T. J., Brenda, L. E., Berg, D. R., Bisson, P. A., MacDonald, L. H., O'Commor, M. D., Olson, P. L., and Steel, E. A.: Fundamental elements of ecologically healthy watersheds in the Pacific Northwest Coastal ecoregion, p. 127-188, in: Watershed Management: Balancing Sustainability and Environmental Change, edited by: Naiman, R. J., Springer-Verlag, New York, 1992.

Nilsson, C., Jansson, R., Malmqvist, B., and Naiman, R. J.: Restoring riverine landscapes: the challenge of identifying priorities, reference states, and techniques, Ecol. Soc., 12, 16, 2007.

Ouimet, W. B., Whipple K. X., Crosby, B. T., Johnson, J. P., and Schildgen, T. F.: Epigenetic gorges in fluvial landscapes, Earth Surf. Proc. Land., 33, 1993-2009, 2008.

Palmer, M. A., Bernhardt, E. S., Allan, J. D., Lake, P. S., Alexander, G., Brooks, S., Carr, J., Clayton, S., Dahm, C., Follstad Shah, J., Galat, D. L., Gloss, S., Goodwin, P., Hart, D. H., Hassett, B., Jenkinson, R., Kondolf, G. M., Lave, R., Meyer, J. L., O’Donnell, T. K., Pagano, L., Srivastava, P., and Sudduth, E.: Standards for ecologically successful river restoration, J. Appl. Ecol., 42, 208-217, 2005.

Pas Water Authority: available at: http://www.chcantabrico. es/index.php?option=com_content $\backslash \&$ view=article $\backslash \&$ id $=$ $211 \% 3$ Aotros-escenarios-de-restauracion $\backslash \&$ catid $=124 \%$ 3 Arestauracion-de-rios $\backslash \&$ Itemid $=154 \backslash \&$ lang=es, last access: 6 June 2011.

Pasquale, N., Perona, P., Schneider, P., Shrestha, J., Wombacher, A., and Burlando, P.: Modern comprehensive approach to monitor the morphodynamic evolution of a restored river corridor, Hydrol. Earth Syst. Sci., 15, 1197-1212, doi:10.5194/hess-151197-2011, 2011.

Poff, N. L., Allan, J. D., Bain, M. B., Karr, J. R., Prestegaard, K. L., Richter, B. D., Sparks, R. E., and Stromberg, J. C.: The Natural Flow Regime: A paradigm for river conservation and restoration, BioScience, 47, 769-784, 1997.

Poole, G. C., Stanford, J. A., Running, S. W., and Frissell, C. A.: Multiscale geomorphic drivers of groundwater flow paths: subsurface hydrologic dynamics and hyporheic habitat diversity, J. N. Am. Benthol. Soc., 25, 288-303, 2006.

Reeves, G. H., Benda, L. E., Burnett, K. M., Bisson, P. A., and Sedell, J. R.: A disturbance-based ecosystem approach to maintaining and restoring freshwater habitats of evolutionarily significant units of anadromous salmonids in the Pacific Northwest. Pages 334-349, in: Evolution and the Aquatic Ecosystem: Defining Unique Units in Population Conservation, edited by: Nielson, J. L. and Powers, D. A., American Fisheries Society Symposium 17, American Fisheries Society, Bethesda, Maryland, USA, 1995.

Rice, R. M., Kiffney, P. M., Greene, C., and Pess, G.: The ecological importance of tributaries and confluences, Pages 209-237, in: River Confluences, Tributaries and the Fluvial Network, edited by: Rice, R. M., Roy, A. G., and Rhoads, B. L., John Wiley and Sons Ltd., 2008.

Rice, S. P., Greenwood, M. T., and Joyce, C. B.: Macroinvertebrate community changes at coarse sediment recruitment points along two gravel bed rivers, Water Resour. Res., 37, 2793-2803, 2001.

Rodríguez-Blanco, M. L., Taboada-Castro, M. M., and TaboadaCastro, Mt. T.: Linking the field to the stream: soil erosion and sediment yield in a rural catchment, NW Spain, Cantena, in Press, 2011.

Rosgen, D.: Applied River Morphology. Wildland Hydrology, Pagosa Springs, Colorado, 1996.

Schumm, S. A.: The Fluvial System, Pages 338, in: John Wiley and Sons, New York, 1977. 
Sedell, J. R. and Luchessa, K. J.: Using the Historical Record as an Aid to Salmonid Habitat Enhancement, Pages 210-223, in: Symposium on Aquisition and Utilization of Aquatic Habitat Inventory Information, Portland, Oregon, 1981.

Sidle, R. C.: A dynamic model of slope stability in zero-order basins, IAHS Publ., 165, 101-110, 1987.

Standford, J. A. and Ward, J. V.: The hyporheic habitat of river ecosystems, Nature, 335, 64-66, 1988.

Thoms, M. C. and Parsons, M.: Eco-geomorphology: an interdisciplinary approach to river science, Pages 113-119, in: The Structure, Function and Management Implications of Fluvial Sedimentary Systems, IAHS, Alice Springs, Australia, 2002.
Ward, J. V., Tockner, K., Arscott, D. B., and Claret, C.: Riverine landscape diversity, Freshwater Biology, 47, 517-539, 2002.

Wohl, E., Angermeier, P. L., Bledsoe, B., Kondolf, G. M., MacDonnell, L., Merritt, D. M., Palmer, M. A., Poff, N. L., and Tarboton, D.: River restoration, Water Resour. Res., 41, 1-12, doi:10.1029/2005WR003985, 2005. 